Article

\title{
Reverse Electrodialysis: Potential Reduction in Energy and Emissions of Desalination
}

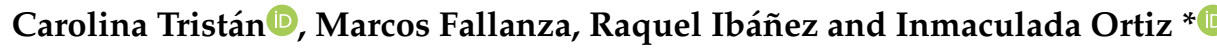 \\ Department of Chemical and Biomolecular Engineering, University of Cantabria, Av. Los Castros 46, \\ 39005 Santander, Spain; tristanc@unican.es (C.T.); fallanzam@unican.es (M.F.); ibanezr@unican.es (R.I.) \\ * Correspondence: ortizi@unican.es; Tel.: +34-942-201-585
}

Received: 29 August 2020; Accepted: 9 October 2020; Published: 19 October 2020

Featured Application: This work examines relevant factors in reverse electrodialysis (RED) application in desalination plants to reach a more sustainable and clean water supply portfolio. Specifically, our work quantifies the energy and emissions savings stemmed from reverse electrodialysis (RED) clean energy generated out of desalination's concentrate effluents through simulation. This assessment may assist in the selection of optimal working conditions, make explicit the decisive factors on RED's performance and devise strategies to enhance energy conversion according to site-specific factors. The technical and environmental assessment may be useful in the prospective advancements towards full-scale RED technology deployment in energy-intensive processes such as desalination.

\begin{abstract}
Salinity gradient energy harvesting by reverse electrodialysis (RED) is a promising renewable source to decarbonize desalination. This work surveys the potential reduction in energy consumption and carbon emissions gained from RED integration in 20 medium-to-large-sized seawater reverse osmosis (SWRO) desalination plants spread worldwide. Using the validated RED system's model from our research group, we quantified the grid mix share of the SWRO plant's total energy demand and total emissions RED would abate (i) in its current state of development and (ii) if captured all salinity gradient exergy (SGE). Results indicate that more saline and warmer SWRO brines enhance RED's net power density, yet source availability may restrain specific energy supply. If all SGE were harnessed, RED could supply $\sim 40 \%$ of total desalination plants' energy demand almost in all locations, yet energy conversion irreversibility and untapped SGE decline it to $\sim 10 \%$. RED integration in the most emission-intensive SWRO plants could relieve up to $1.95 \mathrm{~kg} \mathrm{CO}_{2}$-eq m${ }^{-3}$. Findings reveal that RED energy recovery from SWRO concentrate effluents could bring desalination sector sizeable energy and emissions savings provided future advancements bring RED technology closer to its thermodynamic limit.
\end{abstract}

Keywords: salinity gradient; renewable energy; electro-membrane process; global warming potential; waste-to-wealth; sustainability

\section{Introduction}

The rising water demand and the steady decline in conventional water resources are urging the use of non-conventional ones, as desalinated, re-used or reclaimed water [1,2]. Over the period of 2014 to 2040, the energy use in the water sector is expected to more than double, primarily driven by desalination [3].

Even though membrane technology's advances, installation of energy recovery devices and use of more efficient pumps have well declined the energy to drive desalination over the last four decades [4-6], seawater reverse osmosis (SWRO) desalination remains an energy-intensive source of 
water $[4,5]$. Indeed, the specific energy consumption (SEC) — the energy consumed per cubic meter of water desalted-of current state-of-the-art SWRO plants ranges from $2.5-6.0 \mathrm{kWh} \mathrm{m}^{-3}$ depending on several site-specific factors such as seawater composition and temperature, permeate quality standards, brine management, production capacity and reverse osmosis (RO) configuration [6,7]. The high specific energy use, thereby, thwarts widespread use and environmental sustainability of desalination, as this process relies heavily on conventional power sources. Given that global desalination capacity is projected to increase at a steep pace in the coming years [1,3], and fossil fuels dwarf the current electricity portfolio [8], the shift to low-emissions decentralized renewable power sources with little water needs is decisive in moving forward the gradual decarbonization of the desalination industry.

Unlike solar and wind, innately intermittent and stochastic sources, challenging a stable and safe energy supply, salinity gradient is a clean and steady renewable energy source that may offer an integrated solution to the desalination sector as it reinforces the phaseout of conventional water-intensive energy sources. Salinity gradient energy (SGE), released when two solutions at different concentration spontaneously mix, is converted into useful work through reversible mixing of these two streams in engineered processes; pressure-retarded osmosis (PRO) and reverse electrodialysis (RED) are the most promising technologies among those developed to date [9-11]. Both are somewhat close to commercialization, but the high cost and current performance of membranes along with fouling issues prevent their widespread deployment. PRO uses semi-permeable membranes that allow transportation of water, but not ions, from a low-concentration solution (e.g., seawater, river water, brackish or wastewater) to a high-concentration solution (e.g., seawater, desalination brines) to pressurize water that generates electricity driving mechanical turbines, while RED is an emerging electrochemical process that uses ion-exchange membranes (IEMs) to directly draw electric power from the flow of ions and IEM electric potential difference. The advantage of RED over PRO is that it directly transforms SGE into electricity with no intermediate energy conversion stages (i.e., mechanical into electric). RED is also less prone to fouling issues, and thus can reasonably sustain performance over longer periods.

In RED (Figure 1), the high- and low-salinity solutions (HC and LC, respectively) flow through a series of alternate cation-exchange membranes-CEMs, permeable to cations-and anion-exchange membranes-AEMs, permeable to anions-kept apart by spacers. Each alternate layer of HC and LC compartments adjacent to CEMs and AEMs makes up the cell pair. Several basic repeating units (or cell pairs) stacked in series between two endplates housing the electrodes form the RED pile. The driving force-i.e., the salinity gradient-along with IEM selectivity cause cations and anions to move across the ion-selective membranes from the high salinity side to the low salinity one towards the cathode and the anode, respectively, where redox reactions transform the ionic flux into an electron flux. The chemical potential difference between the concentrate and diluate solutions also gives rise to an electric potential difference over each membrane. The electric current (electron flux) and the electric potential yielded by the RED pile power the external load connected to the end electrodes [12].

RED enables the harnessing of energy from abundant yet largely untapped sources, as industrial effluents, thus providing energy and emission savings from an otherwise waste stream, conforming with the waste-to-wealth concept. Several authors have explored the energy retrieval from desalination concentrate effluents [9,13-18], and secondary treated wastewater effluents [19-22], which bring higher power densities than the seawater/river water pair widely tested in previous works [19,23-25]. While latest research advances have boosted the maturity level of RED, moving from lab-scale units to up-scaled prototypes and pilot plants [11,26], full-scale RED progress will require further techno-economic and environmental assessments and field demonstrations in industrially relevant environments that prove its practical viability. Demonstration projects are limited to the RED pilot plant commissioned next to the Ettore-Infersa saltworks in Trapani (Italy) using saturated brine from the adjacent saltworks and brackish water from a shoreline well, realizing $330 \mathrm{~W}$, and the RED pilot plant at Afsluitdijk (The Netherlands) using seawater from the Wadden Sea and freshwater from Lake Issel with a nominal capacity of $50 \mathrm{~kW}$. To date, fundamental-based studies and experimental investigations have examined the implementation of RED to recover energy from desalination 
concentrate effluents assessing separately endogenous-e.g., RO configuration, water recovery rate, specific energy consumption and capacity—and exogenous—e.g., seawater conditions and electricity mix - factors relevant to the real RO desalination process, overlooking global variations. While these studies have provided insights on how (i) working conditions-concentration [13-16,18,27-29], flow rate $[15,16,28]$ and temperature $[13,16,29]$ of feed solutions-(ii) configuration-i.e., RED acting as pre- and/or post-treatment to RO desalination [13,15,27]—and (iii) even the combination with other technologies to increase concentrate's salinity-e.g., membrane distillation [29], membrane capacitive deionization [18] and solar evaporation [14]—affect RED performance and, therefore, desalination SEC decrease and concentrate effluent dilution, consideration of all these factors at once has not yet been fully investigated and could pinpoint the appropriateness for full-scale RED implementation from the technical and environmental side.

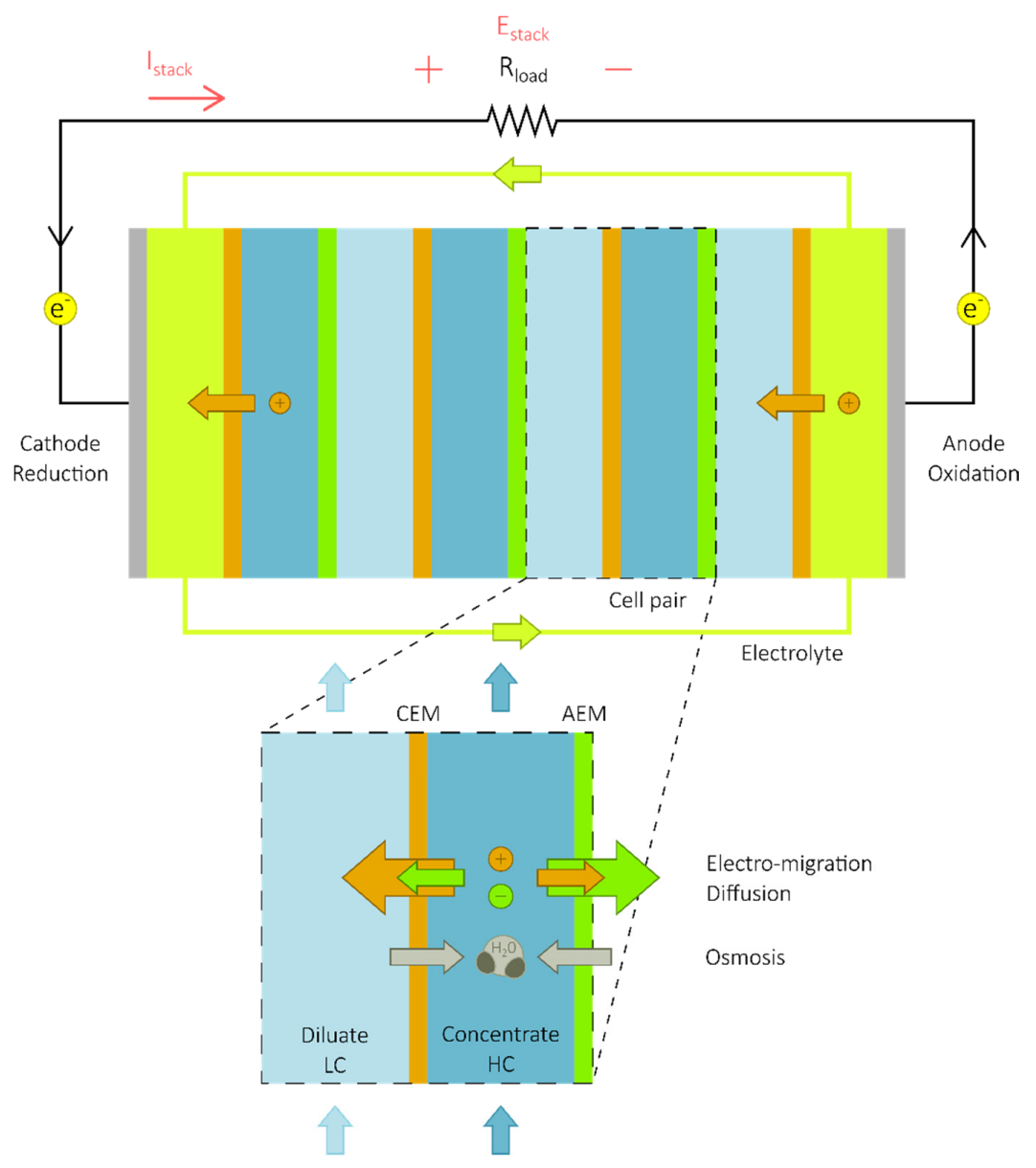

Figure 1. Working principle of reverse electrodialysis (RED).

This work has been one of the first attempts to thoroughly examine the potential energy savings and environmental benefits for desalination stemmed from RED's energy recovered from brine effluents using a comprehensive modelling tool of the RED system from our research group. Our study delves into the relative influence of site-specific conditions and features relevant to real SWRO desalination plants to size the potential energy and emissions savings full-scale RED implementation could offer to the energy- and emission-intensive desalination industry. This work aims to ascertain decisive factors on the RED system's performance which, alongside particular features of desalination plants, bounds the ability of RED integration to cut down energy and emissions to desalination. The insights gained from our assessment may be useful in the prospective decisions to fully exploit the synergies of RED deployment in energy-intensive processes. 


\section{Methods}

\subsection{Scenarios for RED Implementation: SWRO Desalination Plants}

We simulated RED system energy retrieval from a low saline stream, reversibly mixed with the concentrate effluent of 20 medium-to-large capacity SWRO desalination plants distributed worldwide (Table 1). For each location, we set average values of concentrate feed concentration, temperature and flow rate according to seasonal records reported in the literature. The volume and concentration of the concentrate effluent, if not readily available, were estimated solving mass balance for each SWRO plant according to (i) the overall RO configuration; (ii) the water recovery rate RR-i.e., the volume of desalted water to feed water volume-and (iii) the product water and feed seawater salinity. Appendix C details more information on SWRO desalination plants.

Table 1. Scenarios for RED implementation: Specifications of seawater reverse osmosis (SWRO) desalination plants. Data from $[1,6]$.

\begin{tabular}{|c|c|c|c|c|c|c|}
\hline \multirow{2}{*}{ ID } & \multirow{2}{*}{$\begin{array}{c}\text { SWRO } \\
\text { Plant }\end{array}$} & \multirow{2}{*}{$\begin{array}{c}\text { SEC } \\
\left(\mathrm{kWh} \mathrm{m}^{-3}\right)\end{array}$} & \multirow{2}{*}{$\mathrm{T}\left({ }^{\circ} \mathrm{C}\right)$} & \multirow{2}{*}{$\begin{array}{c}\text { Capacity } \\
\left(\mathrm{m}^{3} \text { day }^{-1}\right)\end{array}$} & \multicolumn{2}{|c|}{ Concentrate } \\
\hline & & & & & $\left(\mathrm{mol} \mathrm{L}^{-1}\right)$ & $\left(m^{3} m^{-3}\right)^{1}$ \\
\hline 1 & $\begin{array}{l}\text { Al Dur } \\
\text { [30] }\end{array}$ & 5.4 & 28 & 218,000 & 1.33 & 1.53 \\
\hline 2 & $\begin{array}{c}\text { Barcelona } \\
\text { [31] }\end{array}$ & 4.2 & 19 & 200,000 & 1.23 & 1.39 \\
\hline 3 & $\begin{array}{c}\text { Beni Saf } \\
{[32,33]}\end{array}$ & 4.1 & 25 & 200,000 & 1.16 & 1.13 \\
\hline 4 & $\begin{array}{c}\text { Carlsbad } \\
{[34,35]}\end{array}$ & 3.6 & 18 & 190,000 & 1.14 & 1.24 \\
\hline 5 & $\begin{array}{c}\text { El Coloso } \\
{[36]}\end{array}$ & 4.3 & 17 & 45,630 & 1.25 & 1.00 \\
\hline 6 & $\begin{array}{c}\text { Fujairah I } \\
\text { [37] }\end{array}$ & 4.5 & 29 & 170,500 & 1.10 & 1.44 \\
\hline 7 & $\begin{array}{c}\text { Fukuoka } \\
\text { [38-40] }\end{array}$ & 5.5 & 20 & 50,000 & 1.49 & 0.76 \\
\hline 8 & $\begin{array}{c}\text { Glen Rocky } \\
{[41,42]}\end{array}$ & 3.0 & 20 & 1400 & 1.06 & 1.50 \\
\hline 9 & $\begin{array}{c}\text { Kindasa } \\
\text { [43] }\end{array}$ & 4.6 & 27 & 34,000 & 1.36 & 1.09 \\
\hline 10 & $\begin{array}{c}\text { Los Cabos } \\
{[44,45]}\end{array}$ & 3.5 & 20 & 20,736 & 1.04 & 1.04 \\
\hline 11 & $\begin{array}{c}\text { Maspalomas } \\
\text { II } \\
{[46,47]} \\
\text { Mundo }\end{array}$ & 3.8 & 20 & 26,184 & 1.67 & 0.67 \\
\hline 12 & $\begin{array}{c}\text { Nobo } \\
{[46]}\end{array}$ & 4.2 & 27 & 10,200 & 1.54 & 0.72 \\
\hline 13 & $\begin{array}{l}\text { Nemmeli } \\
\text { Qingdao }\end{array}$ & 3.9 & 28 & 150,000 & 1.21 & 1.22 \\
\hline 14 & $\begin{array}{l}\text { Baifa } \\
\text { [48] }\end{array}$ & 3.5 & 24 & 100,000 & 0.86 & 1.45 \\
\hline 15 & $\begin{array}{l}\text { Sadara } \\
\text { [49] }\end{array}$ & 4.4 & 27 & 148,800 & 1.40 & 1.33 \\
\hline 16 & $\begin{array}{c}\text { SingSpring } \\
{[50,51]}\end{array}$ & 4.1 & 31 & 136,400 & 0.98 & 1.33 \\
\hline 17 & $\begin{array}{c}\text { Sorek } \\
\text { [52-54] }\end{array}$ & 3.5 & 27 & 540,000 & 1.06 & 1.24 \\
\hline 18 & $\begin{array}{l}\text { Sydney } \\
\text { [54-56] }\end{array}$ & 3.9 & 20 & 250,000 & 1.13 & 1.38 \\
\hline 19 & $\begin{array}{c}\text { Tampa Bay } \\
{[57,58]}\end{array}$ & 3.4 & 32 & 95,000 & 1.13 & 0.75 \\
\hline 20 & $\begin{array}{c}\text { Wonthaggi } \\
\text { [59] }\end{array}$ & 4.2 & 16 & 450,000 & 1.11 & 1.40 \\
\hline
\end{tabular}

${ }^{1}$ Concentrate effluent volume per $\mathrm{m}^{3}$ of total permeate produced. 
The proper pairing of SWRO concentrate effluent with a low salinity stream will be a decisive factor in RED's feasible implementation. Hence, we computed the inlet diluate's concentration and flow rate with the RED system mathematical model to maximize the net power output of the RED stack. The optimal concentration range $(35-55 \mathrm{mM})$ is of practical occurrence and may be obtained from natural resources-e.g., estuaries, river basins or anthropogenic ones-for instance, by blending a secondary wastewater effluent $1-20 \mathrm{mM}[15,19,21]$ with a more saline stream as seawater or a 2nd RO pass' concentrate effluent.

\subsection{Estimation of RED's Technical Performance: Net Power and Specific Energy}

We assessed the performance of the up-scaled RED system-i.e., the net power production and net energy recovery of the RED plant-in every scenario, in the process simulation software Aspen Plus ${ }^{\circledR}$ V11 (AspenTech, Bedford, MA, USA) [60], importing a custom RED stack model implemented in Aspen Custom Modeler ${ }^{\circledR}$ V11 (AspenTech) [61]. All simulations refer to a commercial RED unit (Fumatech $\mathrm{GmbH}^{\circledR}$, St. Ingbert, Germany) with an assumed number of cell pairs (cp) representative of industrial-scale stacks reported in the literature (Table 2) [20,62].

Table 2. Parameters of the commercial RED stack (Fumatech GmbH ${ }^{\circledR}$, Germany).

\begin{tabular}{cc}
\hline Parameter & Value \\
\hline Number of cell pairs, $\mathrm{N}_{\mathrm{cp}}(-)$ & 1000 \\
Channel size, b $(\mathrm{m}) \times \mathrm{L}(\mathrm{m})$ & $0.383 \times 0.456$ \\
Spacers & \\
Thickness, $\delta_{\mathrm{sp}}(\mu \mathrm{m})$ & $270^{1}$ \\
Porosity, $\mathcal{\varepsilon}(-)$ & $82.5 \%$ \\
Reference properties: fumasep ${ }^{\circledR}$ CEM (FKS-50)/AEM (FAS-50) \\
Areal resistance, $\mathrm{R}_{\mathrm{IEM}}\left(\Omega \mathrm{cm}^{2}\right)$ & $1.8 / 0.6^{2}$ \\
Permselectivity, $\alpha_{\mathrm{IEM} 0}(-)$ & $0.97 / 0.92^{3}$ \\
Thickness dry, $\delta_{\text {IEM }}(\mu \mathrm{m})$ & 50 \\
Active area, $\mathrm{A}_{\mathrm{m}, \text { eff }}=\mathrm{b} \times \mathrm{L}\left(\mathrm{m}^{2}\right)$ & 0.175 \\
\hline
\end{tabular}

${ }^{1}$ Equal to inter-membrane distance-i.e., height of the high- or low-salinity (HC or LC) channels. ${ }^{2}$ Measured in $0.5 \mathrm{M} \mathrm{NaCl}$ at $25^{\circ} \mathrm{C} .{ }^{3}$ Measured in $0.5 \mathrm{M} \mathrm{NaCl}$ at $25^{\circ} \mathrm{C}$.

We developed a RED system mathematical model, fully descrived in Ortiz et al. [24] and Tristán et al. [63], and extensively validated it in several works of our research group $[19,24,25,64]$ to predict RED performance in a wide range of working conditions at different descriptive extents from cell pair to plant scale [63].

We estimated the SGE recovery potential in every scenario according to (i) the maximum work attainable (thermodynamic limit), which reduces to the Gibbs free energy of mixing, Equation (A1); and (ii) the net specific energy (net energy per cubic meter of desalted water), and net power density (net power per membrane pair effective area) of the RED system under net power optimal working conditions-diluate concentration, diluate and concentrate flowrate and electric current (Table 3)—of the RED stack. We performed parametric evaluations in Aspen Plus to identify the optimal working conditions in each location [63]. Assuming:

- High-pressure (HP) RO pass' concentrate effluent was fully and evenly fed to the high-saline compartments of the RED units;

- Equal temperature-set according to location—for both concentrate and diluate streams;

- Unlimited diluate feed volume for energy conversion. 
Table 3. Working conditions of the RED stack for each scenario and RED plant's layout.

\begin{tabular}{|c|c|c|c|c|c|c|c|}
\hline \multirow{2}{*}{ Scenario } & \multicolumn{2}{|c|}{$\mathrm{C}\left(\mathrm{mol} \mathrm{L}^{-1}\right)$} & \multicolumn{2}{|c|}{$\mathrm{v}\left(\mathrm{cm} \mathrm{s}^{-1}\right)^{2}$} & \multirow{2}{*}{$\mathrm{T}\left({ }^{\circ} \mathrm{C}\right)^{1}$} & \multicolumn{2}{|c|}{$I(A)^{2}$} \\
\hline & $\mathrm{HC}^{1}$ & $\mathrm{LC}^{2}$ & $\mathrm{HC}$ & LC & & Parallel & Series \\
\hline 1 & 1.33 & 0.045 & 1.30 & 2.28 & 28 & 10.48 & 7.16 \\
\hline 2 & 1.23 & 0.045 & 1.02 & 1.79 & 19 & 8.05 & 5.30 \\
\hline 3 & 1.16 & 0.040 & 1.18 & 2.00 & 25 & 8.82 & 5.93 \\
\hline 4 & 1.14 & 0.045 & 1.02 & 1.73 & 18 & 7.48 & 4.91 \\
\hline 5 & 1.25 & 0.045 & 0.97 & 1.68 & 17 & 7.63 & 5.01 \\
\hline 6 & 1.10 & 0.040 & 1.30 & 2.23 & 29 & 9.39 & 6.31 \\
\hline 7 & 1.49 & 0.050 & 1.13 & 1.95 & 20 & 9.44 & 6.44 \\
\hline 8 & 1.06 & 0.040 & 1.02 & 1.79 & 20 & 7.40 & 4.82 \\
\hline 9 & 1.36 & 0.045 & 1.30 & 2.23 & 27 & 10.35 & 7.15 \\
\hline 10 & 1.04 & 0.040 & 1.02 & 1.73 & 20 & 7.32 & 4.73 \\
\hline 11 & 1.67 & 0.055 & 1.13 & 2.01 & 20 & 10.09 & 6.96 \\
\hline 12 & 1.54 & 0.050 & 1.30 & 2.28 & 27 & 11.28 & 7.87 \\
\hline 13 & 1.21 & 0.045 & 1.30 & 2.22 & 28 & 9.98 & 6.71 \\
\hline 14 & 0.86 & 0.035 & 1.07 & 1.84 & 24 & 7.04 & 4.46 \\
\hline 15 & 1.40 & 0.045 & 1.30 & 2.22 & 27 & 10.58 & 7.28 \\
\hline 16 & 0.98 & 0.035 & 1.30 & 2.23 & 31 & 8.97 & 5.93 \\
\hline 17 & 1.06 & 0.040 & 1.18 & 2.11 & 27 & 8.81 & 5.79 \\
\hline 18 & 1.13 & 0.040 & 1.02 & 1.79 & 20 & 7.68 & 5.05 \\
\hline 19 & 1.13 & 0.040 & 1.34 & 2.35 & 32 & 10.16 & 6.79 \\
\hline 20 & 1.11 & 0.040 & 0.91 & 1.62 & 16 & 6.81 & 4.44 \\
\hline
\end{tabular}

$\overline{1}$ Annual average properties of high-pressure (HP) RO pass' concentrate effluent (Table 1). ${ }^{2}$ Optimal net power working conditions computed with RED's model.

The RED plant layout combines series and parallel arrangements of the RED units (Figure 2) to even out the power output and energy yield of the whole system; however, the salinity gradient-i.e., the driving force-declines through the downstream series units, thus undermining the net power density of the RED plant. Hence, to quantify the highest power density and energy yield attainable in each scenario, we computed the RED plant's supply under optimal net power conditions for two hydraulic configurations of the RED units: a multi-stage (series) and a single-stage (parallel) arrangement (Figure 2). The series layout provides the maximum specific energy, since it recovers a larger fraction of the SGE for conversion, while the parallel layout offers the highest power density, as all the RED units process the largest concentration gradient.

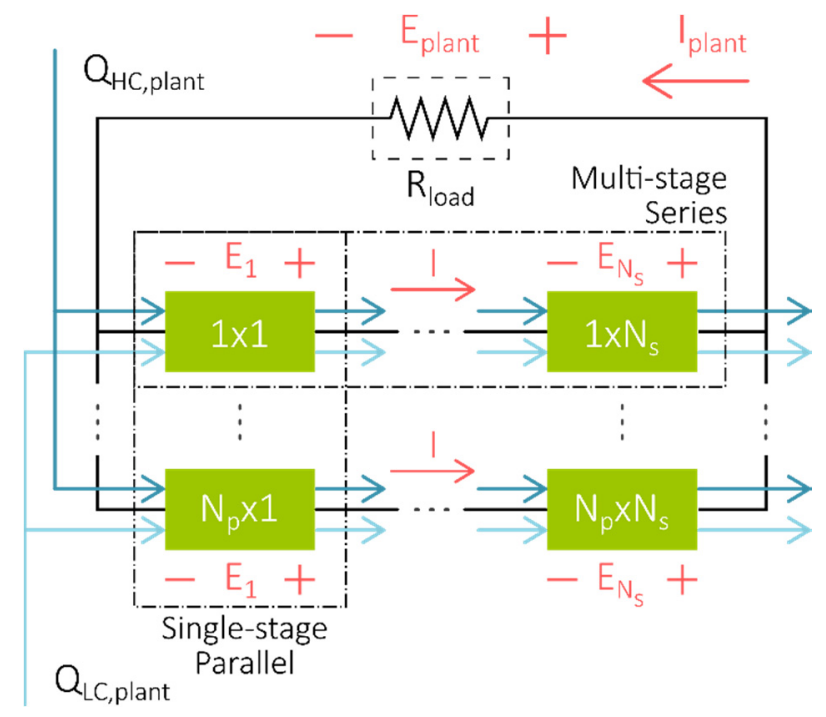

Figure 2. RED plant's layout: $\mathrm{N}_{\mathrm{p}}$ parallel branches each with $\mathrm{N}_{\mathrm{s}}$ stacks arranged in series. 
The maximum number of parallel branches—or parallel stacks in the single-stage layout- $\left(\mathrm{N}_{\mathrm{p}}\right.$, Figure 2) installed in the RED plant was set according to flow rate ratio of HP RO pass' brine $\left(\mathrm{Q}_{\mathrm{HC} \text {,plant }}\right.$, Figure 2) to concentrate inlet per RED stack; the number of RED units arranged in series $\left(\mathrm{N}_{\mathrm{s}}\right.$, Figure 2$)$, assumed equal in all scenarios, maximizes the net power output of the whole series network, which peaks at seven series RED stacks. In the multi-stage arrangement, the RED unit's concentrate and diluate outlet streams are directly fed to the next series stack. The 1st unit in each parallel train works with equal conditions-concentration (C), linear cross-flow velocity (v), temperature (T) and electric current (I) - to that reported in Table 3; the remainder series units run with the same electric current as of the 1st stack (series electric control). The electric current was fine-tuned to maximize the net power output of the whole system, which was reduced in the series arrangement to sustain the concentration gradient over the series-as it slows down electromigration of ions from concentrate to diluate compartments.

\subsection{Estimation of GHG Emissions: Global Warming Potential (GWP)}

The Greenhouse gas (GHG) emissions savings were quantified using the 100-year Global Warming Potential $\left(\mathrm{GWP}_{100}\right)$ metric as defined in the Intergovernmental Panel on Climate Change (IPCC) Model, 100-year time horizon, Fifth Assessment Report, 2013.

The $\mathrm{GWP}_{100}$ in units of mass of carbon dioxide equivalents per cubic meter of desalted water (computed with Equation (A4)) was estimated assuming RED supplies to the SWRO plant (i) the maximum attainable energy-i.e., the difference between the salinity gradient exergy —as defined by Equation (A1), entering and leaving the RED plant (Retrieved Exergy); (ii) the actual energy output of the RED system (Net Specific Energy, computed with the RED system's model). The aforementioned scenarios were compared to the business-as-usual (BaU) scenario where the local grid mix fulfils the energy requirements of the SWRO plant.

The local grid mix's GWP 100 indicator per unit of electricity produced was retrieved from the ecoinvent database 3.6 [65] (dataset: market for electricity, medium voltage, Appendix B). The GWP 100 of the industrial-scale RED stack was estimated based on the Tristán et al. [66] life cycle assessment (LCA) of a RED unit equal to that of our assessment, normalized to the energy yield (net specific energy or specific salinity gradient exergy retrieved for conversion) over the lifetime of the RED plant (20 years) in each location and energy supply scenario (Appendix B).

\section{Results and Discussion}

The site-specific factors affecting the RED system's technical performance are (i) the properties-i.e., ionic composition, concentration and temperature-and (ii) availability (volume) of the feed streams that, alongside (iii) the energy needed to power desalination-SEC, in $\mathrm{kWh}$ per $\mathrm{m}^{3}$ of desalted water produced - and (iv) the energy source of the SWRO desalination plant-i.e., the local electricity mix -will bound the energy and emissions RED could save to desalination plants. The following sections discuss the relative influence of the aforesaid factors, both from the technical and environmental side, on potential grid mix shifted and emissions abated by an up-scaled RED system in 20 globally-distributed medium-to-large-sized SWRO desalination plants.

\subsection{Net Power Density and Net Specific Energy of the RED System}

The quality (feed concentration and temperature) and availability (feed flow rate) of the local energy source (i.e., SGE) will be the drivers in RED technical performance. Using the RED system's model, we conducted simulations to estimate the optimal net power density (net power output per membrane pair area of the single-stage arrangement, Figure 2) and maximum net specific energy (net energy per cubic meter of desalted water of the single-parallel layout, Figure 2) attainable when the RED plant recovers energy from SWRO plants' concentrate effluent-with reported seasonal average concentration, temperature and volume of $0.86-1.67 \mathrm{M}, 16-32{ }^{\circ} \mathrm{C}$ and $0.67-1.57 \mathrm{~m}^{3}$ per $\mathrm{m}^{3}$ of total 
permeate produced; Tables 1 and 3-and the optimal low-salinity stream that maximizes the net power output in every location (with concentration ranging from 35 to $55 \mathrm{mM}$, Table 3).

The concentration and temperature of RED's inlet streams will determine the net power density of the system; the more concentrated and warmer the feeds, the larger the net power output of the RED plant (green to yellow hues in the map, Figure 3) [29,67-69]. As such, the SWRO plants located in the Middle East (i.e., scenarios 1, 9 and 15), suppling the most concentrated and warmest brine effluent to RED, enhance the net power density $\left(3.6-3.7 \mathrm{~W} \mathrm{~m}^{-2}\right.$ per cell pair; Figure 3) peaking to $\sim 4.0 \mathrm{~W} \mathrm{~m}^{-2}$ per cell pair in scenario 12 . Similarly, locations where the high temperature $\left(32{ }^{\circ} \mathrm{C}\right.$, scenario 19$)$ or the high concentration $(1.67 \mathrm{M}$, scenario 11$)$ of the concentrate feed offsets the adverse effect of its lower concentration $(1.13 \mathrm{M})[24,25]$ or temperature $\left(20^{\circ} \mathrm{C}\right)[24,67,69]$ bring about improved net power densities ( $3.5 \mathrm{~W} \mathrm{~m}^{-2}$ per cell pair and $3.4 \mathrm{~W} \mathrm{~m}^{-2}$ per cell pair, respectively). Conversely, the net power density almost halves $\left(\sim 2.1 \mathrm{~W} \mathrm{~m}^{-2}\right.$ per cell pair) in scenarios with opposite working conditions (e.g., scenarios 14 and 20; Figure 3), where RED draws energy from the coldest and more diluted SWRO concentrate effluents.

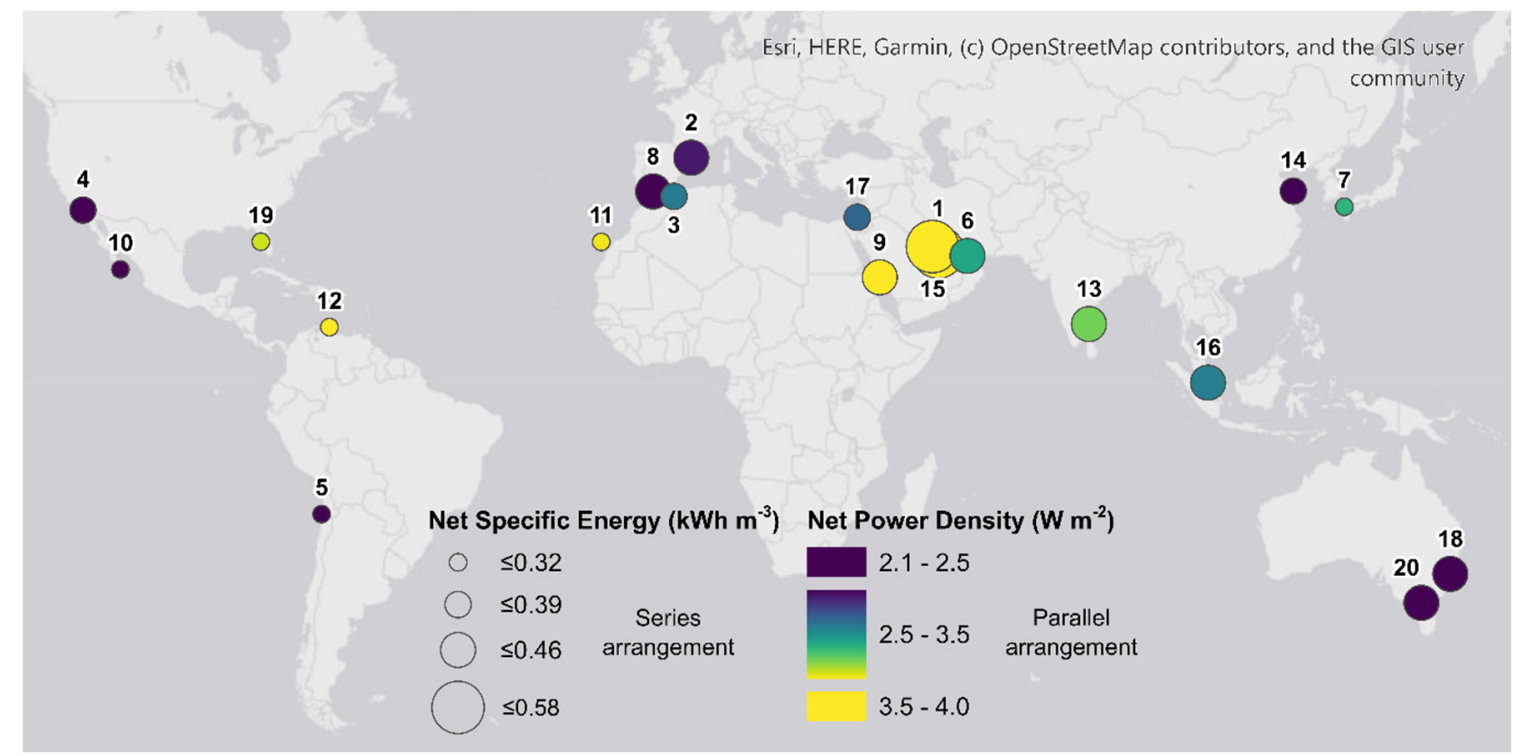

Figure 3. Performance of the RED system: Net Specific Energy-i.e., Net Energy per $\mathrm{m}^{3}$ of desalted water, of the series-parallel network-and Net Power Density-i.e., Net Power per membrane pair active area, of the parallel arrangement. Series arrangement: seven industrial-scale RED units in series; number of parallel RED units set according to the total flowrate of SWRO's brine available for conversion and the flowrate of concentrate stream fed to each RED unit.

Besides feed solutions' properties, the volume availability will be equally vital to realize substantial energy savings to desalination, as it limits the potential specific energy supply of the RED plant (which scales with bubble size in Figure 3). For instance, the scant SWRO brine volume in scenarios 11, 12 and $19\left(0.67-0.75 \mathrm{~m}^{3} \mathrm{~m}^{-3}\right.$ due to the high water recovery rate of these desalination plants of up to $60 \%$; Table A2 hinders the energy capacity of the RED plant $\left(\sim 0.30 \mathrm{kWh} \mathrm{m}^{-3}\right.$, Figure 3$)$, despite the enhanced net power density gained in these scenarios. In contrast, desalination plants in scenarios 15 and 1 supply twice the brine effluent volume $\left(1.33-1.53 \mathrm{~m}^{3} \mathrm{~m}^{-3}\right)$ to that of scenarios 11,12 and 19 , which in turn doubles the net specific energy $\left(0.46-0.58 \mathrm{kWh} \mathrm{m}^{-3}\right)$. Even scenarios where RED implementation yields lower net power densities (e.g., scenarios 20, 18, 8 and 2) become appealing given its larger net specific energy $\left(0.40-0.44 \mathrm{kWh} \mathrm{m}^{-3}\right)$.

Overall, scenarios 1 and 15 hold the most desirable site features for RED implementation-i.e., high concentration and temperature (high net power density) - along with large brine volume (high net specific energy), unlike scenarios 5 and 10, which combine soft temperature and/or low concentration 
(Table 2) and limited concentrate volume (Table 1), where the net power density and net specific energy capacity of the RED plant are greatly diminished, thus making them less suited for RED implementation, followed by scenarios 4 and 14, as the SWRO plant provides slightly more concentrate volume for conversion (Table 1).

\subsection{Energy Savings to Desalination from RED}

While energy resource quality (i.e., feed concentration and temperature) and quantity (feed volume) significantly affect RED performance and thus appropriateness for implementation, it is the SWRO plant's energy demand (SEC ranging from 3.0-5.5 kWh per cubic meter of water desalted across selected emplacements) what will ultimately define the potential energy savings RED could offer to desalination. Building on RED plant's performance assessment, we estimated that the grid mix share of total desalination plants' SEC RED could relieve (i) if reached the thermodynamic limit-Gibbs free energy of mixing, Equation (A1)—and (ii) in the current state of development (Net Specific Energy).

Figure 4 displays the salinity gradient energy share of total SEC of desalination plants along with the respective SEC values (given in the relevant references listed in Table 1); the Gibbs free energy per unit volume of desalted water entering the RED system-denoted in Figures 4 and 5 by the pie chart's green and yellow sectors-sets the upper energy savings to drive desalination [70]. If all salinity gradient's chemical energy was converted to useful work, almost in all scenarios, RED's energy supply could potentially save $33 \%$ to $42 \%$ to desalination plants except Fukuoka (scenario 7, Figure 4), where the exergy input hardly reaches a quarter of its specific energy demand (22\%), and Glen Rocky (scenario 8, Figure 4) where, as opposed to Fukuoka, the SEC is more than halved (57\%). Even so, as the overall energy balance among locations (left graph in Figure 5) infers, the net energy output of the RED plant differs from the maximum extractable work (Input exergy (In), Figure 5), given (i) RED's energy conversion process is irreversible (Pump and Internal losses, Figure 5), and (ii) a fraction of the attainable SGE remains untapped (Out, Figure 5), which altogether makes up the Gibbs free energy unused and wasted ( $U+W \Delta G_{\text {mix }}$, denoted by the green sector in Figures 4 and 5). Overall, the exergy recovered for conversion (Retrieved Exergy, Figure 5)-i.e., the difference between the exergy entering and leaving the RED system-accounts for $86-90 \%$ of the input exergy, of which $26 \%$ to $31 \%$ is converted to useful work, resulting in net energy yield of the RED plant-i.e., the input exergy fraction converted to useful work-of 22-28\% (Net, Figure 5); the net energy output of the RED plant thereby could meet $\sim 10 \%$ of SWRO plant's demand in all locations, aside from two opposed scenarios already instanced: Fukuoka (scenario 7, Figure 4), where the net energy's share is halved as it features the highest SEC along with the lowest net specific energy (Net SE, Figure 3), and Glen Rocky (scenario 8, Figure 4), where the RED plant satisfy $\sim 14 \%$ of the SWRO plant's needs since it is the least energy-demanding desalination plant. Interestingly, although the Al Dur facility (scenario 1) is as energy-intensive as Fukuoka, the net energy share is doubled provided the net specific energy delivered to Al Dur $\left(0.58 \mathrm{kWh} \mathrm{m}^{-3}\right)$ is twice Fukuoka's $\left(0.28 \mathrm{kWh} \mathrm{m}^{-3}\right)$.

These results denote that there is room for improvements to bridge the gap between the thermodynamic limit and the actual energy the RED system produces (i.e., increase the yellow sector; Figures 4 and 5). Not only the plant layout but also the stack design of RED should be systematically optimized to make more efficient use of these waste streams, thereby increasing the RED's energy share of the SWRO plant's supply. The most suitable engineering solution for RED optimization requires minimizing the stack internal electric resistance (Figure 5), especially diluate compartments' contribution $\left(\mathrm{R}_{\mathrm{LC}}\right)$ - given its low conductivity compared to IEM ( $\mathrm{R}_{\mathrm{CEM}}$ and $\mathrm{R}_{\mathrm{AEM}}$ ) and concentrate compartments' $\left(\mathrm{R}_{\mathrm{HC}}\right)$-which makes up half RED stack's internal resistance. In this regard, the use of thinner conductive spacers or profiled membranes may substantially enhance RED process efficiency but may also lead to higher hydrodynamic losses [11]. As such, limiting hydraulic friction losses will involve a thorough design of compartments' geometry opting for hydrophobic materials. As it is the second contribution to RED's internal resistance, novel IEM designs, notably cation-exchange 
membranes, with advanced features (higher ionic conductivity and selectivity) [11] will be as vital as diluate compartments to make RED more efficient.

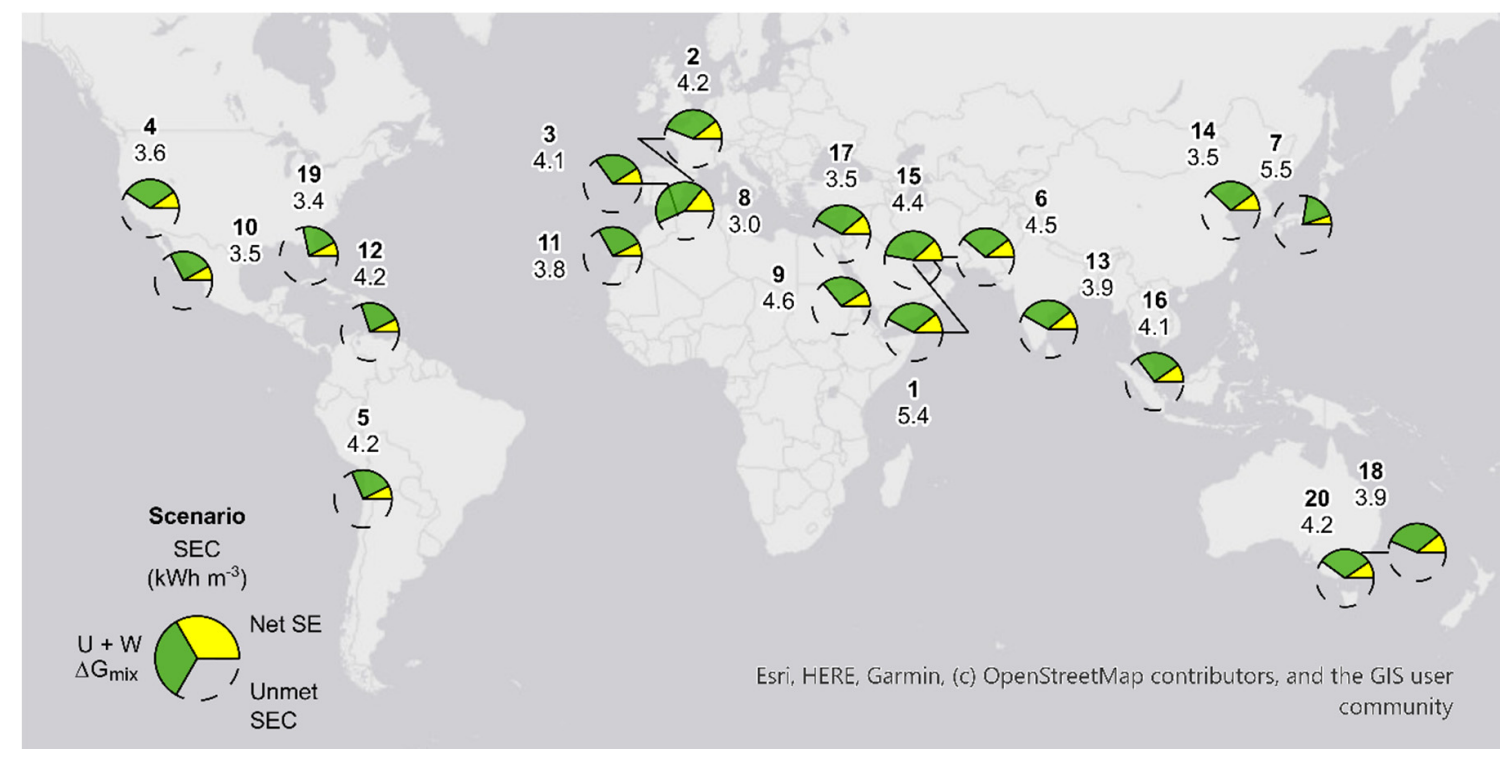

Figure 4. Salinity Gradient Energy share of SWRO desalination plant's energy consumption. The actual SWRO plant's SEC value in $\mathrm{kWh}$ per $\mathrm{m}^{3}$ of desalted water is also displayed (relevant references in Table 1).

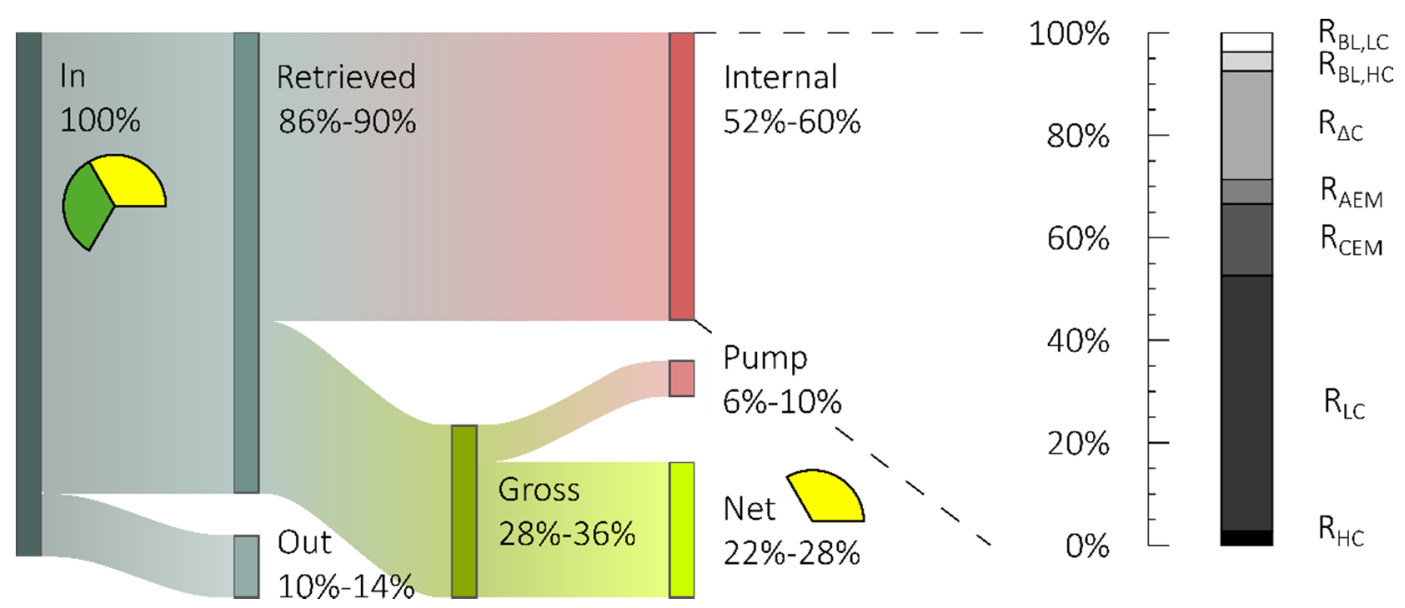

Figure 5. Global-wide energy balance of the RED plant (left), and relative contribution to the internal resistive losses of the 1st RED stack (right).

\subsection{GHG Emissions Savings to Desalination from RED}

To size the emissions RED could save to desalination, we compare the GHG emissions for the BaU energy supply scenario (Mix, denoted by dots in Figure 6), where the local grid mix fully powers the SWRO plant, to that of the Mix+RED scenarios, when RED replaces a fraction of the regional grid mix both in (i) the "optimistic" scenario (Mix+RED emissions' lower limit, Figure 6), where RED transforms all exergy retrieved for conversion into useful work (Retrieved Exergy, Equation (A1)) owing to future advancements in RED technology, and (ii) the "current" scenario (Mix+RED emissions' upper limit, Figure 6), reflecting the current state of RED technology (Net Energy computed with the RED system's model). We applied the 100-year Global Warming Potential metric - $\mathrm{GWP}_{100}, \mathrm{~kg} \mathrm{CO}_{2}$-eq per $\mathrm{m}^{3}$ of desalted water, Equation (A4) - to quantify the GHG emissions for each energy supply scenarios-i.e., $\mathrm{BaU}$ and Mix+RED—and location-i.e., scenarios 1 to 20. 


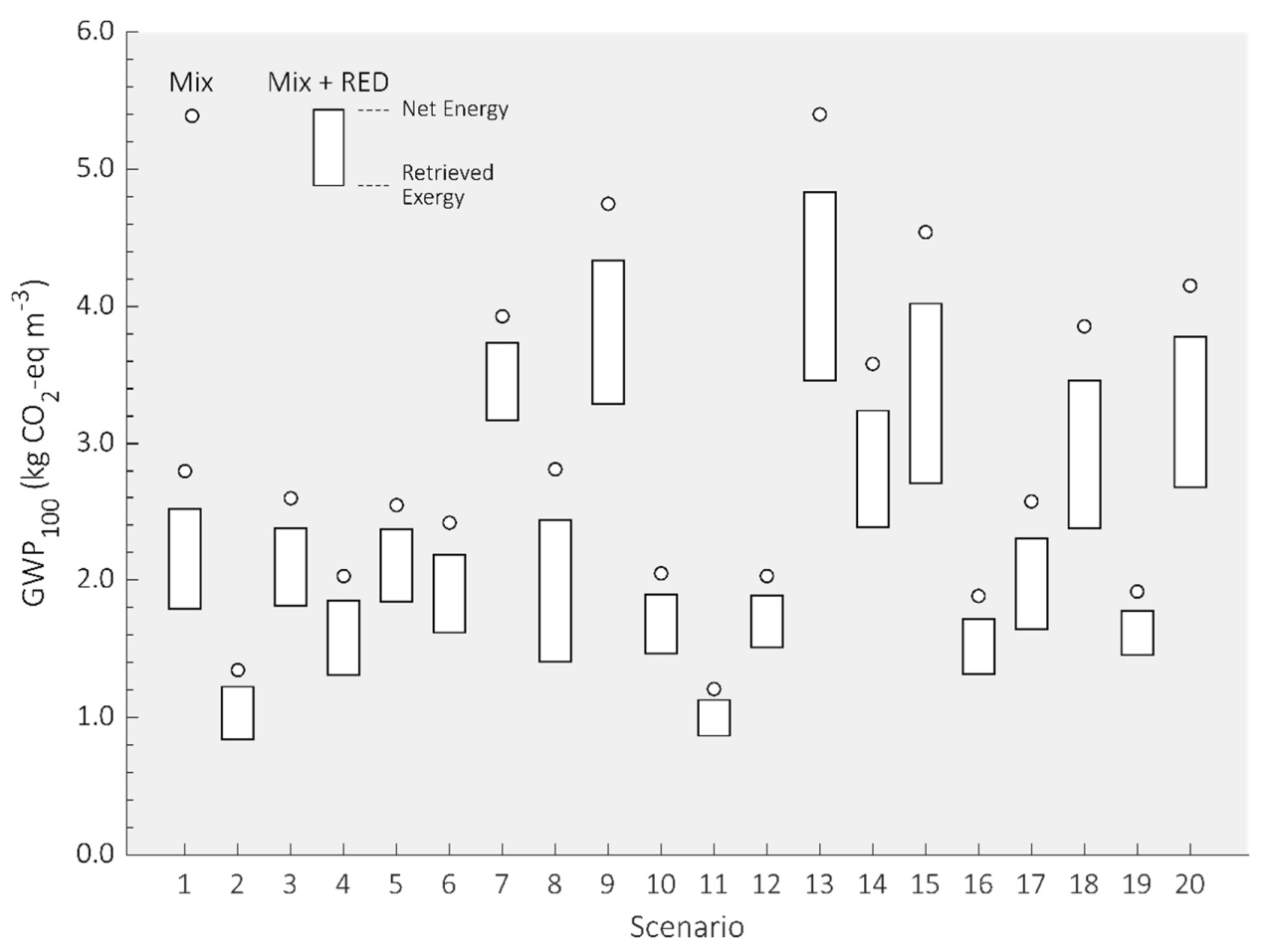

Figure 6. Electricity related GWP per $\mathrm{m}^{3}$ of permeate according to locations (scenarios 1 to 20) for each energy supply scenario. SEC of SWRO plant met by (i) Grid Mix (BaU); (ii) Grid Mix + RED's Net Energy (upper limit, "current" scenario); (iii) Grid Mix + RED's Retrieved Exergy (lower limit, "optimistic" scenario).

RED's salinity gradient energy retrieval from desalination's concentrate effluent is a promising route to balance out carbon emissions from this energy-intensive sector; this is particularly true for those locations deeply reliant on fossil fuels (Table A1 and Figure A1) as some Middle East regions (scenarios 9, 15), Australia (scenarios 18 and 20), China and India (scenarios 14 and 13, respectively). Besides the local electricity portfolio, RED's ability to cut down desalination's carbon emissions hinges on (i) the technical and environmental performance of RED and (ii) the energy required to drive desalination.

Concerning the environmental performance of RED, since all scenarios use the same number of series RED units per parallel branch each working with equal feed conditions-equal concentration, temperature and flow rate per branch, so the net power scales with the number of parallel branches-the differences of RED's GWP per kWh of energy produced among sites depend only on the RED plant's power output (i.e., the power density)—Equation (A6). Hence, the places where RED reaches large power densities (scenarios 12, 15 and 1; Figure 3) will earn lower GWP per kWh (Figure A2); the opposite true for scenarios 20 and 14. Even so, the grid mix share RED saves to SWRO plants greatly offsets the environmental burden allocated to RED, given its little relative contribution, below $\sim 2 \%$, to the overall energy-related GWP of desalination plants both in the "optimistic" and the "current" energy supply scenarios (Equation (A4)). As a result, on average, current-state RED could reduce desalination's GWP by $\sim 10 \%$ raising to $\sim 34 \%$ if RED technology realized future advancements. The lower RED's GWP per kWh (Figure A2), but higher grid mix's GWP per kWh (Figure A1) and lower RED's energy share (Figure 4) in scenario 7, lead RED to save a minimum of $~ 5 \%$ to $20 \%$ in "current" and "optimistic" supply scenarios, respectively, as opposed to scenario 8 , where desalination's emissions savings rise to $\sim 14 \%$ ("current") up to $51 \%$ ("optimistic") compared to the BaU scenario. Although RED provides the largest relative emissions saving in scenario 8-stem from the greatest RED energy share of total SWRO SEC; Figure 4-RED application in emission-intensive desalination plants-as those of scenarios 13, 9, 15 and 20 with high SWRO SEC and electricity mix GWP per kWh-would bring in sizable emission 
reductions, moving from 0.38 (RED's net specific energy) and $1.41 \mathrm{~kg} \mathrm{CO}_{2}$-eq m${ }^{-3}$ (RED's retrieved exergy) in scenario 8 to 0.58 and $1.95 \mathrm{~kg} \mathrm{CO}_{2}$-eq m${ }^{-3}$ in scenario 13.

Desalination plant capacity will define absolute GHG emission reduction; as such, the larger the SWRO plant size and local emission metric (scenario 18, 17 and 20), the greater the absolute annual GHG emissions abated, as high as 36.2-61.1 $\mathrm{kt} \mathrm{CO}_{2}$-eq (up to 183-242 kt CO2-eq in the "optimistic" scenario) reaching a low of $0.2-0.8 \mathrm{kt} \mathrm{CO}_{2}$-eq (0.7-3.2 $\mathrm{kt} \mathrm{CO}_{2}$-eq) in medium-sized SWRO plants located in scenarios 11, 10 and 8. Collectively, RED could potentially save 0.32 ("current") to $1.18 \mathrm{Mt} \mathrm{CO}_{2}$-eq ("optimistic") per year, accounting for around $0.4 \%$ to $1.6 \%$ of global operational desalination plant emissions in 2015 (76 $\mathrm{Mt} \mathrm{CO}_{2}$-eq per year) [71].

\section{Conclusions}

This work assesses the potential energy and emissions savings SGE-RED application, an emerging renewable power technology, could offer to desalination. Using the RED system model, we estimated the technical performance of an up-scaled RED system implemented in 20 medium-to-large-sized SWRO desalination plants spread worldwide with SEC varying from $3.0-5.5 \mathrm{kWh}$ per $\mathrm{m}^{3}$ of desalted water. Building on RED plant's performance assessment, we estimated the grid mix share of total desalination plant energy demand the RED plant could replace in its current state of development (i.e., net specific energy) and if captured all salinity gradient's input exergy. Finally, we quantified the GHG emissions abatement range related to the energy supply of desalination plants, by contrasting the GWP 100 metric when (i) the local electricity mix powers desalination in full and (ii) when RED partly feeds desalination plants in its current state of development (net energy) and if reached the thermodynamic limit (retrieved exergy).

Findings reveal that more saline and warmer SWRO concentrate effluents yield enhanced net power densities, yet source availability restrains specific energy supply in some locations. Desalination plants with high water recovery rate deliver a high-saline, but scarce concentrate stream that increases the net power density, though curbs the specific energy of the RED plant, thus making them less suited locations for RED implementation. The most promising scenarios are those where the RED plant attains high power densities (3.6-3.7 $\mathrm{W} \mathrm{m}^{-2}$ per cell pair) while retains high specific energy (0.46-0.58 $\mathrm{kWh}$ per $\mathrm{m}^{3}$ of total permeate).

Our estimates indicate that nearly in all locations, RED could supply just under two-fifths of total desalination plant energy demand if harnessing all input exergy — well over half in locations where the RED plant delivers high specific energy to the least energy-intensive SWRO plants. Energy conversion process irreversibility alongside untapped fraction of the input exergy, however, declines by one-fourth $(\sim 10 \%$ up to $14 \%)$ the RED plant's share of total desalination plant energy supply. Accounting for over half of the RED stack's internal losses, an optimized design of diluate compartments and development of IEMs with advanced properties (high conductivity and selectivity) would enhance energy conversion efficiency, thus increasing RED's share of SWRO plant energy supply.

Environmentally speaking, the local grid mix's share RED saves to desalination plants outweighs RED's environmental burden contribution to the overall energy-related GHG emissions of desalination plants. On average, in its current state of development, RED could abate by roughly $10 \%$ desalination plant emissions - up to over a third if progress on RED allowed reaching the thermodynamic limit. RED integration in the most emission-intensive SWRO plants provides a sizeable emissions abatement-up to $1.95 \mathrm{~kg} \mathrm{CO}_{2}$-eq $\mathrm{m}^{-3}$ if harnessing all retrieved exergy—though a lower relative reduction in some locations. Even though the emissions emitted per $\mathrm{m}^{3}$ of permeate produced were higher, RED application in large-sized desalination plants would avoid further absolute GHG emissions than in medium-sized ones. Collectively, RED could potentially abate 0.32 to $1.18 \mathrm{Mt} \mathrm{CO}_{2}$-eq per year, representing $0.4 \%$ to $1.6 \%$ of global operational desalination plant emissions in 2015 .

Overall, these findings indicate that RED energy recovery from SWRO concentrate effluents could bring desalination sector sizeable energy and emissions savings provided future advancements bring RED technology closer to its thermodynamic limit. 
Author Contributions: Conceptualization, C.T., M.F. and R.I.; methodology, C.T., M.F. and R.I.; software, C.T.; validation, C.T.; formal analysis, C.T.; investigation, C.T.; resources, M.F. and R.I.; data curation, C.T.; writing-original draft preparation, C.T.; writing—review and editing, M.F., R.I. and I.O.; visualization, C.T.; supervision, M.F., R.I. and I.O.; project administration, R.I. and I.O.; funding acquisition, R.I. and I.O. All authors have read and agreed to the published version of the manuscript.

Funding: This research was funded by the LIFE programme (LIFE19 ENV/ES/000143) and the Spanish Ministry of Science, Innovation and Universities (RTI2018-093310-B-I00 and CTM2017-87850-R, and the FPI grant awarded to C.T., PRE2018-086454).

Conflicts of Interest: The authors declare no conflict of interest.

\section{Glossary}

Symbols

$\Delta \mathrm{G}_{\text {mix }} \quad$ Gibbs free energy of mixing (salinity gradient exergy)

C

Concentration

E Electric potential difference

I Electric current

Q Flow rate

$\mathrm{GWP}_{100} \quad$ 100-year Global Warming Potential metric

$\mathrm{R} \quad$ Ionic resistance of the RED stack

T Temperature

v Linear cross-flow velocity in the RED stack's compartments

Abbreviations

AEM Anion exchange membrane

$\mathrm{BaU}$ Business-as-usual

CEM Cation exchange membrane

IEM Ion exchange membrane

HP High-pressure RO pass

LP Low-pressure RO pass

RED Reverse electrodialysis

RR Water recovery rate

SWRO Seawater reverse osmosis

SEC Specific energy consumption

SE Specific energy of RED

Subscripts

HC High concentration compartment/solution

LC Low concentration compartment/solution

BL Boundary layer's non-ohmic contribution to RED stack's internal resistance

$\Delta C \quad$ Stream-wise concentration gradient's non-ohmic contribution to RED stack's resistance

\section{Appendix A. Salinity Gradient Exergy}

The exergy in RED, given by the Gibbs free energy of mixing $\left(\Delta \mathrm{G}_{\mathrm{mix}}\right)$, indicates the amount of available energy that can be recovered from a system reaching equilibrium. The specific exergy-the exergy per concentrate solution's volume [70]:

$$
\begin{gathered}
\frac{\Delta G_{\text {mix }}}{V_{H C}}=v R T\left(\frac{\Phi}{1-\Phi} C_{L C} \ln \frac{C_{L C}}{C_{M}}+C_{H C} \ln \frac{C_{H C}}{C_{M}}\right) \\
C_{M}=\Phi C_{L C}+(1-\Phi) C_{H C} \\
\Phi=\frac{V_{L C}}{V_{H C}+V_{L C}}
\end{gathered}
$$

where $\Delta \mathrm{G}_{\text {mix }}$ is the change in the Gibbs free energy of mixing $(\mathrm{J}), \mathrm{R}$ is the gas constant $\left(8.314 \mathrm{~J} \mathrm{~mol}^{-1} \mathrm{~K}^{-1}\right)$, $\mathrm{T}$ is the absolute temperature $(\mathrm{K}), v$ is the number of ions each salt molecule dissociates into ( 2 for $\mathrm{NaCl}$ aqueous solutions), $\mathrm{V}$ is the volume $\left(\mathrm{m}^{3}\right)$ and $\mathrm{C}$ is the concentration $\left(\mathrm{mol} \mathrm{m}^{-3}\right)$ of the concentrate 
(HC) and the diluate (LC) aqueous solution before mixing completely. The concentration of the mixed solution in thermodynamic equilibrium $\mathrm{C}_{\mathrm{M}}\left(\mathrm{mol} \mathrm{m}^{-3}\right)$ is given by Equation (A2). $\Phi$, Equation (A3), is the volumetric ratio of diluate solution's initial volume to total volume of the system.

The exergy change between RED plant inlet and outlet streams gives the exergy recovered for conversion-i.e., the retrieved exergy, used to capture the potential GHG emissions savings RED could lend to desalination plants in the "optimistic" Mix+RED energy supply scenario.

\section{Appendix B. Global Warming Potential Metric's Definition}

Equation (A4) defines the desalination plant's 100-year Global Warming Potential $\left(\mathrm{GWP}_{100}\right)$ per cubic meter of desalted water in the BaU $($ Share $=0)$ and the Mix+RED energy supply scenarios:

$$
\begin{gathered}
\mathrm{GWP}_{100}\left(\mathrm{~kg} \mathrm{CO}_{2}-\mathrm{eq} \mathrm{m}^{-3}\right)=\left[(1-\text { Share }) \mathrm{GWP}_{100, \text { mix }}+\text { Share GWP } 100, \text { RED }\right] \text { SEC } \\
\text { Share }=\text { SE } / \text { SEC }
\end{gathered}
$$

where $\mathrm{GWP}_{100 \text {, mix }}$ is the local grid mix $\mathrm{GWP}_{100}$ per unit of electricity produced as specified in IPCC 2013 impact assessment method (retrieved from the ecoinvent database version 3.6 [65]), GWP 100 , RED is the RED plant's GWP 100 in "current" or "optimistic" energy supply scenarios $\left(\mathrm{kg} \mathrm{CO}_{2}\right.$-eq kWh$\left.{ }^{-1}\right), \mathrm{SE}$ is the RED's specific energy supply (Net Specific Energy or Specific Retrieved Exergy in the "current" or "optimistic" energy supply scenarios) in kWh per cubic meter of desalted water, and SEC is the desalination plant's Specific Energy Consumption $\left(\mathrm{kWh} \mathrm{m}^{-3}\right)$.

\begin{tabular}{|c|c|c|c|c|c|c|}
\hline Geography & Fossil Fuels ${ }^{1}$ & Hydro & Nuclear & Renewables $^{2}$ & Waste & Scenario \\
\hline $\begin{array}{l}\text { United Arab Emirates } \\
\text { (AE) }\end{array}$ & $99.8 \%$ & - & - & $0.2 \%$ & - & 6 \\
\hline $\begin{array}{l}\text { Australia } \\
\text { (AU) }\end{array}$ & $87.1 \%$ & $6.8 \%$ & - & $6.1 \%$ & - & 18,20 \\
\hline $\begin{array}{l}\text { Bahrain } \\
(\mathrm{BH})\end{array}$ & $100 \%$ & - & - & - & - & 1 \\
\hline $\begin{array}{l}\text { Chile } \\
\text { (CL) }\end{array}$ & $62.2 \%$ & $33.9 \%$ & - & $3.9 \%$ & - & 5 \\
\hline $\begin{array}{l}\text { China } \\
(\mathrm{CN})\end{array}$ & $78.2 \%$ & $16.7 \%$ & $2.0 \%$ & $3.0 \%$ & - & 14 \\
\hline $\begin{array}{l}\text { Curaçao } \\
(\mathrm{CW})\end{array}$ & $46.4 \%$ & - & - & $53.6 \%$ & - & 12 \\
\hline $\begin{array}{l}\text { Algeria } \\
\text { (DZ) }\end{array}$ & $99.5 \%$ & $0.4 \%$ & - & $0.1 \%$ & - & 3 \\
\hline $\begin{array}{l}\text { Spain } \\
\text { (ES) }\end{array}$ & $32.5 \%$ & $16.4 \%$ & $26.6 \%$ & $24.4 \%$ & $0.1 \%$ & 2,11 \\
\hline $\begin{array}{l}\text { Gibraltar } \\
\text { (GI) }\end{array}$ & $100 \%$ & - & - & - & - & 8 \\
\hline $\begin{array}{l}\text { Israel } \\
\text { (IL) }\end{array}$ & $100 \%$ & - & - & - & - & 17 \\
\hline $\begin{array}{l}\text { India } \\
\text { (IN) }\end{array}$ & $82.7 \%$ & $10.5 \%$ & $2.9 \%$ & $3.9 \%$ & - & 13 \\
\hline $\begin{array}{l}\text { Japan } \\
\text { (JP) }\end{array}$ & $86.6 \%$ & $8.9 \%$ & $2.0 \%$ & $1.0 \%$ & $1.5 \%$ & 7 \\
\hline $\begin{array}{l}\text { Mexico } \\
(\mathrm{MX})\end{array}$ & $81.0 \%$ & $11.4 \%$ & $4.1 \%$ & $3.4 \%$ & - & 10 \\
\hline $\begin{array}{l}\text { Saudi Arabia } \\
\text { (SA) }\end{array}$ & $100 \%$ & - & - & - & - & 9,15 \\
\hline $\begin{array}{l}\text { Singapore } \\
\text { (SG) }\end{array}$ & $96.7 \%$ & - & - & $0.5 \%$ & $2.7 \%$ & 16 \\
\hline $\begin{array}{l}\text { United States } \\
\text { (US) }\end{array}$ & $64.6 \%$ & $7.4 \%$ & $20.1 \%$ & $7.5 \%$ & $0.4 \%$ & 4,19 \\
\hline
\end{tabular}

Table A1. Local electricity supply mix including imports. Data from [65].

${ }^{1}$ Hard coal; lignite; industrial gases; oil; natural gas. ${ }^{2}$ Geothermal; solar PV; solar thermal; wind; biogas; biomass. 


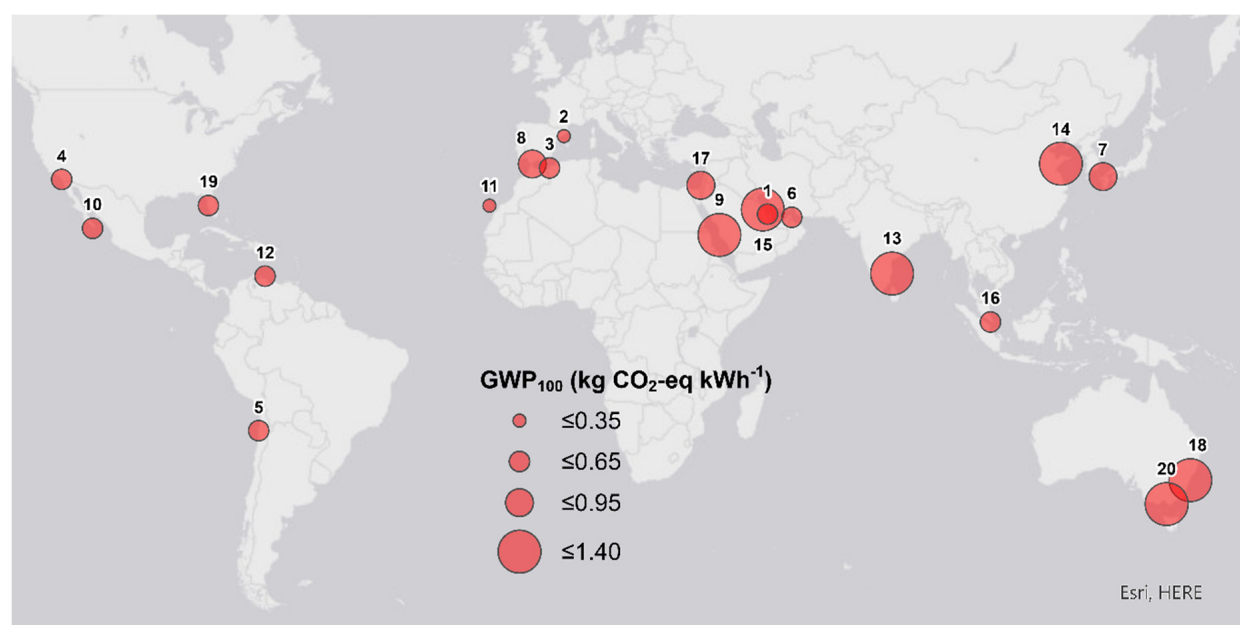

Figure A1. The 100-year Global Warming Potential of the electricity mix. Impact assessment method: IPCC 2013. Dataset: market for electricity, medium voltage, Allocation, cut-off by classification. Geography: Table A1. Database: ecoinvent version 3.6. Data from ecoinvent [65].

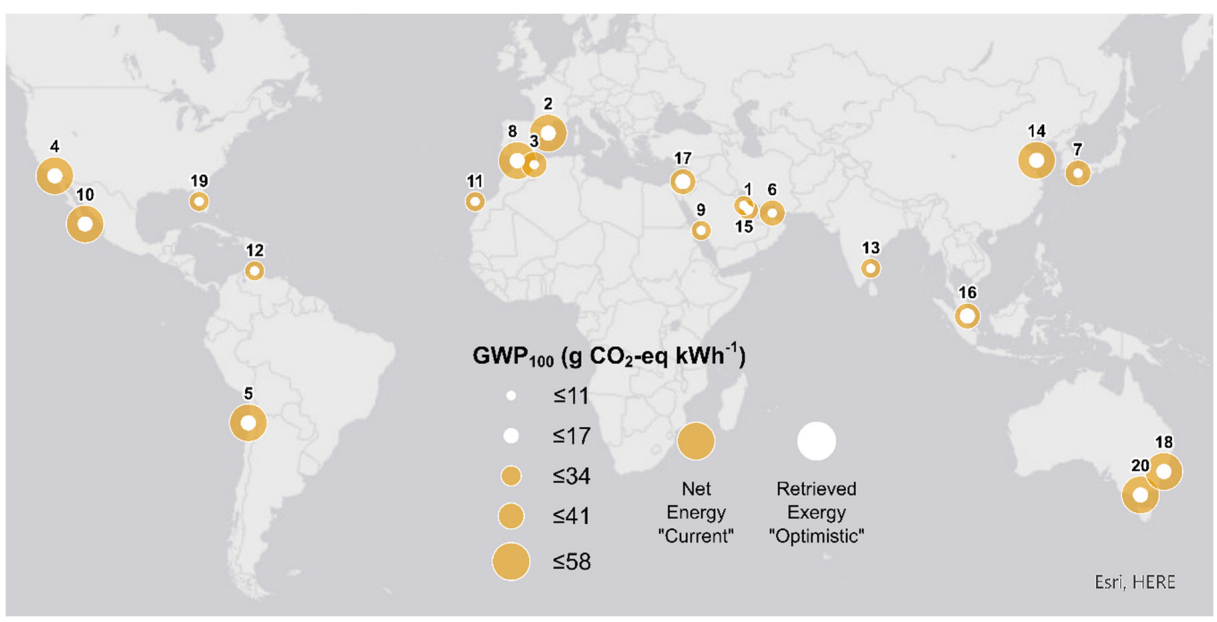

Figure A2. The 100-year Global Warming Potential of the RED plant derived from Equation (A6) in the "current" (Net Energy) and "optimistic" (Retrieved Exergy) energy supply scenarios. RED stack: 1000 cell pairs, $0.175 \mathrm{~m}^{2}$ effective membrane area per cell pair (Table 2). RED stack's working conditions reported in Table 3.

The GWP $\mathrm{P}_{100}$ per $\mathrm{kWh}$ of a RED plant with $\mathrm{N}_{\mathrm{p}}$ parallel trains each with $\mathrm{N}_{\mathrm{s}}$ series RED units was computed as follows:

$$
\operatorname{GWP}_{100, \operatorname{RED}}\left(\mathrm{kg} \mathrm{CO}_{2}-\mathrm{eq} \mathrm{kWh}{ }^{-1}\right)=\frac{\mathrm{N}_{\mathrm{s}} \mathrm{N}_{\mathrm{p}} \mathrm{GWP}_{100, \text { RED stack }}}{\mathrm{E}_{\text {plant }} \text { LT }}
$$

where $\mathrm{GWP}_{100}$, RED stack is the GWP of the RED stack ( $\mathrm{kg} \mathrm{CO}_{2}$-eq) as defined in Tristán et al.'s LCA [66], and $E_{\text {plant }}$ and LT are the retrieved exergy yield or net energy yield $\left(\mathrm{kWh} \mathrm{year}^{-1}\right)$ and the lifetime (20 years) of the RED plant, respectively.

The annual energy yield of a RED plant working at full capacity-i.e., 8760 full load hours per year (FLH)—is given by:

$$
\mathrm{E}_{\text {plant }}\left(\mathrm{kWh} \text { year }^{-1}\right)=\left(\mathrm{N}_{\mathrm{p}} \sum_{\mathrm{i}=1}^{\mathrm{N}_{\mathrm{s}}} \mathrm{P}_{\mathrm{i}}\right) \text { FLH }
$$

where $P_{i}$ is the capacity of each series RED unit (Table 2) under operating conditions reported in Table 3 , either in "current" (net power) or "optimistic" (retrieved exergy flow) energy supply scenarios (kW). 


\section{Appendix C. SWRO Desalination Plants' Specifications}

The RED plant retrieves energy from the rejected brine of the high pressure (HP) RO pass (HC feed RED, Figure A1) paired with the optimal diluate feed stream of the RED stack. To estimate the concentration and flow rate of the HP RO pass' concentrate effluent (not directly disclosed in some scenarios), we set out mass balances for each SWRO plant considering the following reported data (i) the overall RO configuration, (ii) the water recovery rate RR and (iii) the salinity of final permeate and feed seawater.

Figure A1 depicts the simplified scheme of some RO configurations given in Table A1. In a single-pass two-stage RO configuration (1P and $2 \mathrm{~S}$ Figure A3a), the concentrate effluent of the 1st RO stage or pass is further treated in a 2nd RO stage to enhance the overall water recovery rate and final permeate's quality. The permeate of the 1st and 2nd RO stages makes up the final permeate of the SWRO plant. In a partial two-pass RO system (P2P, Figure A3b), a portion of the 1st RO pass' permeate is further treated in a 2nd RO pass, while the remaining permeate effluent is directly blended with the permeate produced by the 2nd RO pass. The 2nd RO pass' concentrate effluent is returned to the 1 st pass feed to enhance the overall water recovery rate. In a four-stage cascade configuration (C, Figure A3c), the 1st and 2nd RO stages comprise the Split-Partial Second Pass stage (SP2P), which is an advance partial-two pass RO design. In an SP2P configuration, the permeate produced by the rear elements of the 1st RO pass' pressure vessel is further polished in a 2nd RO pass (the second pass treats a smaller, but more saline stream than a conventional partial two-pass system), and the permeate produced by the front elements of the 1st RO pass' pressure vessel is directly blended with the 2nd and 4th RO stage permeate. The 3rd and 4th RO stages comprise the conventional full two-pass (F2P) RO stage that processes the 2nd RO pass' concentrate effluent of the SP2P stage. The 3rd RO permeate effluent is sent to the last stage (4th RO stage) of the plant.
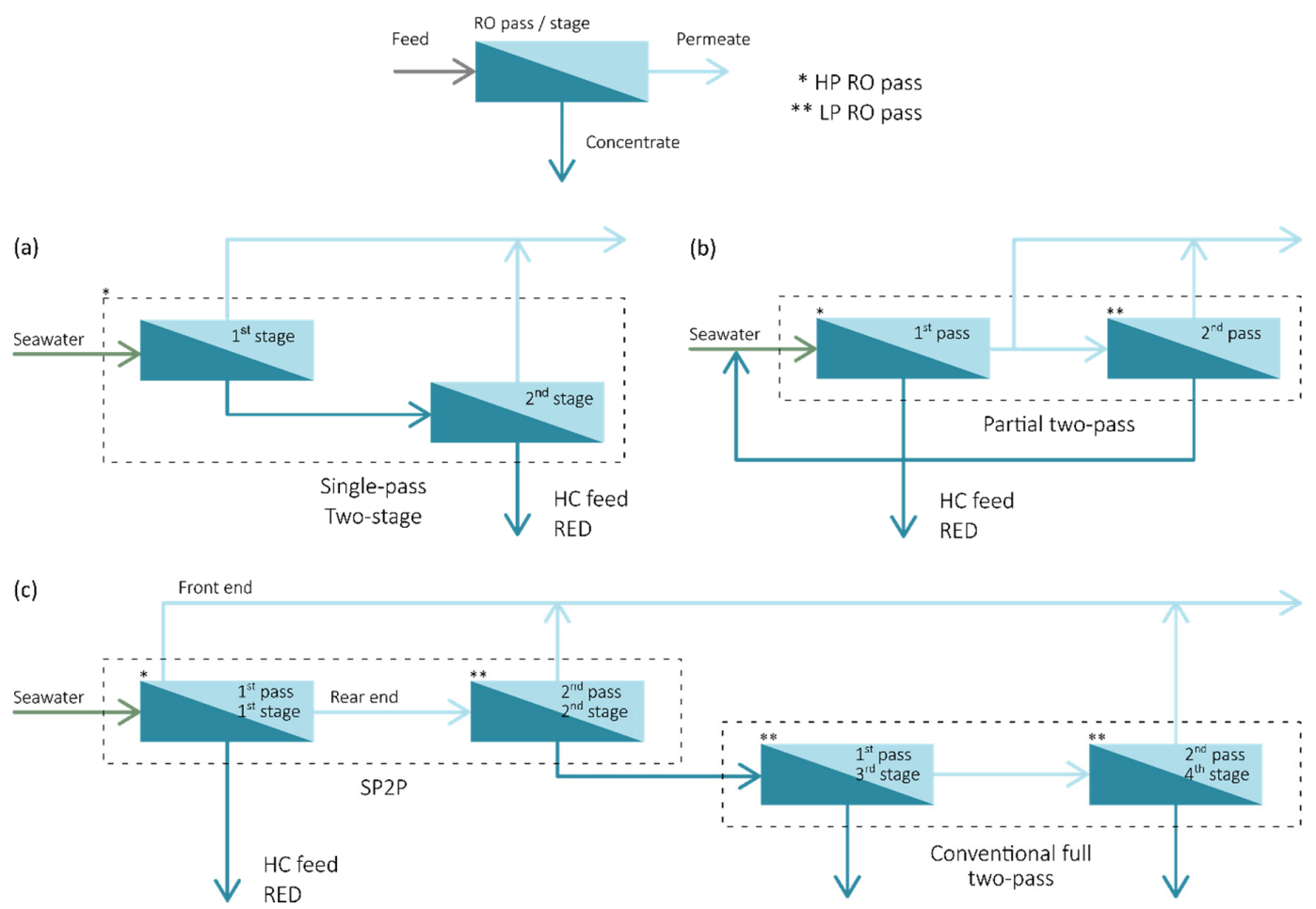

Figure A3. Overall RO configuration of some SWRO desalination plants: (a) Single-pass (1P) with a two-stage configuration (2S); (b) Generic partial two-pass (P2P); (c) Split partial two-pass (SP2P) with a four-stage cascade configuration (C). High pressure RO pass $\left(\mathrm{HP},{ }^{*}\right)$; Low pressure RO pass $\left(\mathrm{LP},{ }^{* *}\right)$. The RED plant recovers energy from HP RO pass' concentrate effluent (HC feed RED). 
Table A2. RO configuration and water recovery rate of SWRO desalination plants. Data from $[1,6]$.

\begin{tabular}{|c|c|c|c|c|c|}
\hline \multirow{2}{*}{ ID } & \multirow{2}{*}{ SWRO Plant } & \multicolumn{2}{|c|}{ RO Configuration } & \multicolumn{2}{|c|}{ RR (\%) } \\
\hline & & Overall & HP/LP & HP & LP \\
\hline 1 & $\begin{array}{c}\text { Al Dur } \\
{[30]}\end{array}$ & $\mathrm{F} 2 \mathrm{P}$ & $1 S / 2 S$ & 42 & 90 \\
\hline 2 & $\begin{array}{c}\text { Barcelona } \\
\text { [31] }\end{array}$ & $\mathrm{P} 2 \mathrm{P}$ & $1 S / 2 S$ & 45 & 85 \\
\hline 3 & $\begin{array}{c}\text { Beni Saf } \\
{[32,33]}\end{array}$ & $1 \mathrm{P}$ & $1 S / N A$ & 45 & NA \\
\hline 4 & $\begin{array}{c}\text { Carlsbad } \\
{[34,35]}\end{array}$ & SP2P & 1S/C (F2P) & 45 & $\begin{array}{l}85 \\
85 \\
90\end{array}$ \\
\hline 5 & $\begin{array}{c}\text { El Coloso } \\
{[36]}\end{array}$ & $1 \mathrm{P}$ & 1S/NA & 50 & NA \\
\hline 6 & $\begin{array}{c}\text { Fujairah I } \\
\text { [37] }\end{array}$ & $\mathrm{P} 2 \mathrm{P}$ & $1 S / 2 S$ & 43 & 90 \\
\hline 7 & $\begin{array}{c}\text { Fukuoka } \\
\text { [38-40] }\end{array}$ & $\mathrm{P} 2 \mathrm{P}$ & $2 S / 1 S$ & 60 & 85 \\
\hline 8 & $\begin{array}{c}\text { Glen Rocky } \\
{[41,42]}\end{array}$ & $1 \mathrm{P}$ & 1S/NA & 40 & NA \\
\hline 9 & $\begin{array}{l}\text { Kindasa } \\
\text { [43] }\end{array}$ & $\mathrm{P} 2 \mathrm{P}$ & $2 S / 2 S$ & 50 & 90 \\
\hline 10 & $\begin{array}{c}\text { Los Cabos } \\
{[44,45]}\end{array}$ & $1 \mathrm{P}$ & 1S/NA & 49 & NA \\
\hline 11 & $\begin{array}{c}\text { Maspalomas II } \\
{[46,47]}\end{array}$ & $1 \mathrm{P}$ & 2S/NA & 60 & NA \\
\hline 12 & $\begin{array}{c}\text { Mundo Nobo } \\
{[46]}\end{array}$ & $2 \mathrm{P}$ & $2 S / 3 S$ & 40 & $\begin{array}{l}33 \\
90\end{array}$ \\
\hline 13 & Nemmeli & $1 \mathrm{P}$ & 1S/NA & 45 & NA \\
\hline 14 & $\begin{array}{c}\text { Qingdao Baifa } \\
{[48]}\end{array}$ & SP2P & $1 S / 2 S$ & 43 & 90 \\
\hline 15 & $\begin{array}{c}\text { Sadara } \\
\text { [49] }\end{array}$ & $\mathrm{F} / \mathrm{P} 2 \mathrm{P}$ & 1S/NR & 45 & 90 \\
\hline 16 & $\begin{array}{c}\text { SingSpring } \\
{[50,51]}\end{array}$ & $\mathrm{P} 2 \mathrm{P}$ & $1 S / 2 S$ & 45 & 90 \\
\hline 17 & $\begin{array}{c}\text { Sorek } \\
{[52-54]}\end{array}$ & SP2P & $1 S / C$ & 45 & $\begin{array}{l}85 \\
85 \\
90\end{array}$ \\
\hline 18 & $\begin{array}{l}\text { Sydney } \\
\text { [54-56] }\end{array}$ & $\mathrm{P} 2 \mathrm{P}$ & $1 S / 1 S$ & 45 & 86 \\
\hline 19 & $\begin{array}{c}\text { Tampa Bay } \\
{[57,58]}\end{array}$ & $\mathrm{P} 2 \mathrm{P}$ & $1 S / 2 S$ & 57 & 90 \\
\hline 20 & $\begin{array}{c}\text { Wonthaggi } \\
\text { [59] }\end{array}$ & $\mathrm{P} 2 \mathrm{P}$ & $1 S / 2 S$ & 48 & 90 \\
\hline
\end{tabular}

RO configurations (Figure A1): Full two-pass (F2P); Partial two-pass (P2P); Split partial two-pass (SP2P); Single-pass (1P); Single-stage (1S); Two-stage (2S), Cascade (C); RR: Water recovery rate; HP: High pressure RO pass; LP: Low pressure RO pass.

\section{References}

1. GWI; IDA. IDA Water Security Handbook 2018-2019; Media Analytics Ltd.: Oxford, UK, 2018; ISBN 978-1-907467-55-4.

2. UNESCO. UN-Water, 2020: United Nations World Water Development Report 2020: Water and Climate Change; UNESCO: Paris, France, 2020; ISBN 978-92-3-100371-4.

3. IEA. WEO-2016 Special Report: Water-Energy Nexus; IEA: Paris, France, 2016.

4. Voutchkov, N. Energy use for membrane seawater desalination-current status and trends. Desalination 2018, 431, 2-14. [CrossRef] 
5. Amy, G.; Ghaffour, N.; Li, Z.; Francis, L.; Linares, R.V.; Missimer, T.; Lattemann, S. Membrane-based seawater desalination: Present and future prospects. Desalination 2017, 401, 16-21. [CrossRef]

6. Kim, J.; Park, K.; Yang, D.R.; Hong, S. A comprehensive review of energy consumption of seawater reverse osmosis desalination plants. Appl. Energy 2019, 254, 113652. [CrossRef]

7. Ghaffour, N.; Missimer, T.M.; Amy, G.L. Technical review and evaluation of the economics of water desalination: Current and future challenges for better water supply sustainability. Desalination 2013, 309, 197-207. [CrossRef]

8. BP Energy Economics. BP Statistical Review of World Energy, 68th ed.; BP p.l.c.: London, UK, 2019.

9. Yip, N.Y.; Brogioli, D.; Hamelers, H.V.M.; Nijmeijer, K. Salinity gradients for sustainable energy: Primer, progress, and prospects. Environ. Sci. Technol. 2016, 50, 12072-12094. [CrossRef] [PubMed]

10. Logan, B.E.; Elimelech, M. Membrane-based processes for sustainable power generation using water. Nature 2012, 488, 313-319. [CrossRef] [PubMed]

11. Tufa, R.A.; Pawlowski, S.; Veerman, J.; Bouzek, K.; Fontananova, E.; di Profio, G.; Velizarov, S.; Goulão Crespo, J.; Nijmeijer, K.; Curcio, E. Progress and prospects in reverse electrodialysis for salinity gradient energy conversion and storage. Appl. Energy 2018, 225, 290-331. [CrossRef]

12. Pattle, R.E. Production of Electric Power by mixing Fresh and Salt Water in the Hydroelectric Pile. Nature 1954, 174, 660. [CrossRef]

13. Mei, Y.; Tang, C.Y. Co-locating reverse electrodialysis with reverse osmosis desalination: Synergies and implications. J. Membr. Sci. 2017, 539, 305-312. [CrossRef]

14. Brauns, E. An alternative hybrid concept combining seawater desalination, solar energy and reverse electrodialysis for a sustainable production of sweet water and electrical energy. Desalin. Water Treat. 2010, 13, 53-62. [CrossRef]

15. Li, W.; Krantz, W.B.; Cornelissen, E.R.; Post, J.W.; Verliefde, A.R.D.; Tang, C.Y. A novel hybrid process of reverse electrodialysis and reverse osmosis for low energy seawater desalination and brine management. Appl. Energy 2013, 104, 592-602. [CrossRef]

16. Kwon, K.; Han, J.; Park, B.H.; Shin, Y.; Kim, D. Brine recovery using reverse electrodialysis in membrane-based desalination processes. Desalination 2015, 362, 1-10. [CrossRef]

17. Mehdizadeh, S.; Yasukawa, M.; Kuno, M.; Kawabata, Y.; Higa, M. Evaluation of energy harvesting from discharged solutions in a salt production plant by reverse electrodialysis (RED). Desalination 2019, 467, 95-102. [CrossRef]

18. Choi, J.; Oh, Y.; Chae, S.; Hong, S. Membrane capacitive deionization-reverse electrodialysis hybrid system for improving energy efficiency of reverse osmosis seawater desalination. Desalination 2019, 462, $19-28$. [CrossRef]

19. Gómez-Coma, L.; Ortiz-Martínez, V.M.; Fallanza, M.; Ortiz, A.; Ibañez, R.; Ortiz, I. Blue energy for sustainable water reclamation in WWTPs. J. Water Process Eng. 2020, 33, 101020. [CrossRef]

20. Nam, J.-Y.; Hwang, K.-S.; Kim, H.-C.; Jeong, H.; Kim, H.; Jwa, E.; Yang, S.; Choi, J.; Kim, C.-S.; Han, J.-H.; et al. Assessing the behavior of the feed-water constituents of a pilot-scale 1000-cell-pair reverse electrodialysis with seawater and municipal wastewater effluent. Water Res. 2019, 148, 261-271. [CrossRef]

21. Luque Di Salvo, J.; Cosenza, A.; Tamburini, A.; Micale, G.; Cipollina, A. Long-run operation of a reverse electrodialysis system fed with wastewaters. J. Environ. Manag. 2018, 217, 871-887. [CrossRef]

22. Mehdizadeh, S.; Yasukawa, M.; Suzuki, T.; Higa, M. Reverse electrodialysis for power generation using seawater/municipal wastewater: Effect of coagulation pretreatment. Desalination 2020, 481, 114356. [CrossRef]

23. Daniilidis, A.; Vermaas, D.A.; Herber, R.; Nijmeijer, K. Experimentally obtainable energy from mixing river water, seawater or brines with reverse electrodialysis. Renew. Energy 2014, 64, 123-131. [CrossRef]

24. Ortiz-Imedio, R.; Gomez-Coma, L.; Fallanza, M.; Ortiz, A.; Ibañez, R.; Ortiz, I. Comparative performance of Salinity Gradient Power-Reverse Electrodialysis under different operating conditions. Desalination 2019, 457, 8-21. [CrossRef]

25. Ortiz-Martínez, V.M.; Gómez-Coma, L.; Tristán, C.; Pérez, G.; Fallanza, M.; Ortiz, A.; Ibañez, R.; Ortiz, I. A comprehensive study on the effects of operation variables on reverse electrodialysis performance. Desalination 2020, 482, 114389. [CrossRef]

26. Jang, J.; Kang, Y.; Han, J.H.; Jang, K.; Kim, C.M.; Kim, I.S. Developments and future prospects of reverse electrodialysis for salinity gradient power generation: Influence of ion exchange membranes and electrodes. Desalination 2020, 491, 114540. [CrossRef] 
27. Feinberg, B.J.; Ramon, G.Z.; Hoek, E.M.V. Thermodynamic analysis of osmotic energy recovery at a reverse osmosis desalination plant. Environ. Sci. Technol. 2013, 47, 2982-2989. [CrossRef]

28. Yasukawa, M.; Mehdizadeh, S.; Sakurada, T.; Abo, T.; Kuno, M.; Higa, M. Power generation performance of a bench-scale reverse electrodialysis stack using wastewater discharged from sewage treatment and seawater reverse osmosis. Desalination 2020, 491, 114449. [CrossRef]

29. Tufa, R.A.; Noviello, Y.; Di Profio, G.; Macedonio, F.; Ali, A.; Drioli, E.; Fontananova, E.; Bouzek, K.; Curcio, E. Integrated membrane distillation-reverse electrodialysis system for energy-efficient seawater desalination. Appl. Energy 2019, 253, 113551. [CrossRef]

30. Le Gallou, S.; Bertrand, S.; Madan, K.H. Al Dur SWRO plant: A double challenge for pre- and post-treatments. Desalin. Water Treat. 2013, 51, 101-110. [CrossRef]

31. Sanz, M.A.; Miguel, C. The role of SWRO Barcelona-Llobregat Plant in the water supply system of Barcelona Area. Desalin. Water Treat. 2013, 51, 111-123. [CrossRef]

32. Beni Saf Water Station de Dessalement D'eau de Mer de Beni SAF. Available online: http://benisafwater.com/ station/ (accessed on 12 August 2020).

33. Belatoui, A.; Bouabessalam, H.; Hacene, O.R.; De-la-Ossa-Carretero, J.A.; Martinez-Garcia, E.; Sanchez-Lizaso, J.L. Environmental effects of brine discharge from two desalinations plants in Algeria (South Western Mediterranean). Desalin. WATER Treat. 2017, 76, 311-318. [CrossRef]

34. Petersen, K.L.; Heck, N.; Reguero, B.G.; Potts, D.; Hovagimian, A.; Paytan, A.; Lykkebo Petersen, K.; Heck, N.G.; Reguero, B.; Potts, D.; et al. Biological and physical effects of brine discharge from the carlsbad desalination plant and implications for future desalination plant constructions. Water 2019, 11, 208. [CrossRef]

35. EIR—Carlsbad Desal Plant. Available online: https://www.carlsbaddesal.com/eir.html (accessed on 27 August 2020).

36. Petry, M.; Sanz, M.A.; Langlais, C.; Bonnelye, V.; Durand, J.P.; Guevara, D.; Nardes, W.M.; Saemi, C.H. The El Coloso (Chile) reverse osmosis plant. Desalination 2007, 203, 141-152. [CrossRef]

37. Sanz, M.A.; Bonnélye, V.; Cremer, G. Fujairah reverse osmosis plant: 2 years of operation. Desalination 2007, 203, 91-99. [CrossRef]

38. Fukuoka District Waterworks Association Annual Report 2018 Water Quality Test Vol. 28. Available online: http://www.f-suiki.or.jp/waterquality_post/ (accessed on 12 August 2020).

39. Hamano, T. Operation of Fukuoka Sea Water Desalination Plant. Bull. Soc. Sea Water Sci. Jpn. 2006, 60, 415-421. [CrossRef]

40. Kurokawa, K.; Ono, Y.; Koseki, Y.; Sugimoto, K.; Ohkuma, N.; Itsubo, N. Life cycle assessment and life cycle costing of seawater desalination plants using reverse osmosis: Comparison analysis of evaluation results between activities plan stage and actual observations stage. J. Life Cycle Assess. Jpn. 2018, 14, 46-54. [CrossRef]

41. Desalination Plant for Gibraltar-Kirton. Available online: https://www.kirton.co.uk/work/desalinationplant-for-the-rock/ (accessed on 26 August 2020).

42. Quintana Martínez, I. Análisis de la Planta Desaladora de Gibraltar y Optimización de sus Recuperadores de Energía. Master's Thesis, E.T.S.I. Industriales (UPM), Madrid, Spain, February 2018.

43. Gulamhusein, A.H.; Al Sheikh Khalil, A.S.; Fatah, I.A.; Boda, R.; Rybar, S. IMS SWRO Kindasa-Two years of operational experience. Desalin. Water Treat. 2009, 10, 245-254. [CrossRef]

44. Stover, R.; Martin, J. Titan PX-1200 energy recovery device-test results from the inima Los Cabos, Mexico, seawater RO facility. Desalin. Water Treat. 2009, 3, 179-182. [CrossRef]

45. Gutiérrez Zamora, A.; Aguilar Juárez, M.A.; Martínez Cedillo, I. Proyecto de Construcción, Operación, Mantenimiento y Puesta en Marcha de una Planta Desaladora en Cabo San Lucas; Ambios Ecología y Desarrollo: La Paz, Mexique, 2019.

46. Meyer-Steele, S.; von Gottberg, A.; Talavera, J.L. New Sea Water Reverse Osmosis Plant for the Carribean "Energy Recovery, Brine Recovery \& Cost Reduction". In Proceedings of the Caribbean Water and Wastewater Association (CWWA) 10th Annual Conference \& Exhibition, Cayman Islands, UK, 1-5 October 2001.

47. Portillo, E.; de la Rosa, M.R.; Louzara, G.; Quesada, J.; Ruiz, J.M.; Mendoza, H. Dispersion of desalination plant brine discharge under varied hydrodynamic conditions in the south of Gran Canaria. Desalin. Water Treat. 2014, 52, 164-177. [CrossRef] 
48. Li, Y.; Xiong, W.; Zhang, W.; Wang, C.; Wang, P. Life cycle assessment of water supply alternatives in water-receiving areas of the South-to-North Water Diversion Project in China. Water Res. 2016, 89, 9-19. [CrossRef] [PubMed]

49. Balian, M.; Boudinar, M.; Delabie, C.; Easton, C.; Friis-Andersen, M.; Fernandez, M.J.; Le Bideau, S.; Leriquier, S.; Millis, A.; Painchaud, M.; et al. WAVE No7-Desalination. WAVE Insights from Veolia Water Technol. 2017, 7. Available online: https://www.veoliawatertechnologies.com/sites/g/files/dvc2476/files/ document/2019/06/170348_VWT_CORPOC_WAVE_7_LR_Draft_v06.pdf (accessed on 19 October 2020).

50. Research Office LegCo. Seawater Desalination In Singapore Fact Sheet (FSC21/15-16); Research Office. Legislative Council Secretariat: Hong Kong, China, 2015.

51. Fong, L.M. Managing Operations of PPP Contracts Case Study: SingSpring Desalination Plant. Available online: http://environment.asean.org/wp-content/uploads/2013/07/awgrm/Managing-PPP-Contractors(2Nov2012)(PUB).pdf (accessed on 26 August 2020).

52. Kenigsberg, C.; Abramovich, S.; Hyams-Kaphzan, O. The effect of long-term brine discharge from desalination plants on benthic foraminifera. PLoS ONE 2020, 15, e0227589. [CrossRef]

53. Faigon, M. Success behind advanced SWRO desalination plant. Filtr. Sep. 2016, 53, 29-31. [CrossRef]

54. Singh, R. Hybrid Membrane Systems-Applications and Case Studies. In Membrane Technology and Engineering for Water Purification, 2nd ed.; Butterworth-Heinemann (Elsevier): Oxford, UK, 2015; pp. 179-281. ISBN 978-0-444-63362-0.

55. Sydney Desalination Plant, Infrastructure. Available online: https://www.sydneydesal.com.au/how-we-doit/infrastructure/ (accessed on 26 August 2020).

56. Carson, P.; Duffy, W. Environmental Assessment of the Concept Plan for Sydney's Desalination Project; Sydney Water: Parramatta, Australia, 2005.

57. Benjamin, J.; Arias, M.E.; Zhang, Q. A techno-economic process model for pressure retarded osmosis based energy recovery in desalination plants. Desalination 2020, 476, 114218. [CrossRef]

58. Janicki Environmental, I. A Hydrodynamic Model of the Nearshore and Offshore Waters Adjacent to the Proposed Tampa Bay Water Gulf Coast Desalination Facility; Janicki Environmental, Inc.: St. Petersburg, FL, USA, 2003.

59. The State of Victoria Department of Sustainability and Environment. Environmental Effects of Marine Structures; Victorian Government Department of Sustainability and Environment: Melbourne, Australia, 2008; Volume 2, ISBN 978-1-74208-335-3.

60. Aspen Technology, Inc. Aspen Plus; Aspen Technology, Inc.: Bedford, MA, USA, 2019.

61. Aspen Technology, Inc. Aspen Custom Modeler; Aspen Technology, Inc.: Bedford, MA, USA, 2019.

62. Han, J.-H.; Jeong, N.; Kim, C.-S.; Hwang, K.S.; Kim, H.; Nam, J.-Y.; Jwa, E.; Yang, S.; Choi, J. Reverse electrodialysis (RED) using a bipolar membrane to suppress inorganic fouling around the cathode. Water Res. 2019, 166, 115078. [CrossRef]

63. Tristán, C.; Fallanza, M.; Ibáñez, R.; Ortiz, I. Recovery of salinity gradient energy in desalination plants by reverse electrodialysis. Desalination 2020, 496, 114699. [CrossRef]

64. Gómez-Coma, L.; Ortiz-Martínez, V.M.; Carmona, J.; Palacio, L.; Prádanos, P.; Fallanza, M.; Ortiz, A.; Ibañez, R.; Ortiz, I. Modeling the influence of divalent ions on membrane resistance and electric power in reverse electrodialysis. J. Membr. Sci. 2019, 592, 117385. [CrossRef]

65. Wernet, G.; Bauer, C.; Steubing, B.; Reinhard, J.; Moreno-Ruiz, E.; Weidema, B. The ecoinvent database version 3 (part I): Overview and methodology. Int. J. Life Cycle Assess. 2016, 21, 1218-1230. [CrossRef]

66. Tristán, C.; Rumayor, M.; Dominguez-Ramos, A.; Fallanza, M.; Ibáñez, R.; Ortiz, I. Life cycle assessment of salinity gradient energy recovery by reverse electrodialysis in a seawater reverse osmosis desalination plant. Sustain. Energy Fuels 2020, 4, 4273-4284. [CrossRef]

67. Ortega-Delgado, B.; Giacalone, F.; Cipollina, A.; Papapetrou, M.; Kosmadakis, G.; Tamburini, A.; Micale, G. Boosting the performance of a Reverse Electrodialysis-Multi-Effect Distillation Heat Engine by novel solutions and operating conditions. Appl. Energy 2019, 253, 113489. [CrossRef]

68. Giacalone, F.; Vassallo, F.; Griffin, L.; Ferrari, M.C.; Micale, G.; Scargiali, F.; Tamburini, A.; Cipollina, A. Thermolytic reverse electrodialysis heat engine: Model development, integration and performance analysis. Energy Convers. Manag. 2019, 189, 1-13. [CrossRef]

69. Mehdizadeh, S.; Yasukawa, M.; Abo, T.; Kuno, M.; Noguchi, Y.; Higa, M. The effect of feed solution temperature on the power output performance of a pilot-scale reverse electrodialysis (RED) system with different intermediate distance. Membranes 2019, 9, 73. [CrossRef] [PubMed] 
70. Yip, N.Y.; Elimelech, M. Thermodynamic and energy efficiency analysis of power generation from natural salinity gradients by pressure retarded osmosis. Environ. Sci. Technol. 2012, 46, 5230-5239. [CrossRef] [PubMed]

71. Global Clean Water Desalination Alliance. Global Clean Water Desalination Alliance "H20 minus CO2" Concept Paper; Global Clean Water Desalination Alliance: Abu Dhabi, UAE, 2015.

Publisher's Note: MDPI stays neutral with regard to jurisdictional claims in published maps and institutional affiliations.

(C) 2020 by the authors. Licensee MDPI, Basel, Switzerland. This article is an open access article distributed under the terms and conditions of the Creative Commons Attribution (CC BY) license (http://creativecommons.org/licenses/by/4.0/). 